\title{
THE NEW GENEALOGY OF RELIGIOUS FREEDOM
}

\author{
DAVID DECOSIMO
}

Assistant Professor, School of Theology, Boston University

\begin{abstract}
This article pursues an immanent critique of a scholarly movement and mood that I call "the new genealogy of religious freedom" and sketches an alternative proposal. The new genealogy of religious freedom claims that religious freedom is incoherent, systemically biased, oppressive, ideological-and necessarily so. Its critique deploys a methodology inherited from Nietzsche and targets a vision of religious freedom associated with "foundationalists" like Kant and Rawls. This article calls both the methodology and the vision into question. The version of genealogy that this movement promotes proves self-destructive and incoherent, veering toward nihilism and unable to account for its own status as critique. Its attack on foundationalist religious freedom is effective, but it presupposes-and targets-conceptions of freedom, neutrality, and power that we need not endorse. For foundationalists and genealogists alike, these assumptions define religious freedom. This article rejects those assumptions and that vision of religious freedom. It sketches a pragmatist, dialectical vision of religious freedom rooted in alternate conceptions of power, freedom, and neutrality and a corresponding strategy for legally defining "religion," inheriting the strengths of genealogy and foundationalism while avoiding their weaknesses.
\end{abstract}

KEYWORDS: religious freedom, genealogy, power, essentialism, defining religion, pragmatist

This article assesses and responds to a scholarly movement and mood that I call the "new genealogy of religious freedom." The new genealogy claims that religious freedom is impossible, an ideological tool of "Western," secularist oppression, a pernicious deception that exacerbates old conflicts and inaugurates worse ones. The new genealogy may be right about one very influential brand of religious freedom. It is almost certainly right about many particular cases. But it is also mistaken in vital ways. Most importantly, it is mistaken in thinking its critique tells against religious freedom generally or gives us reason to abandon its pursuit. Religious freedom has often served as ideological cover and generated new forms of oppression, division, and violence. But it has not always done so. More significantly, it need not always do so. That is the claim of this article.

What religious freedom amounts to depends on our conceptions of religion and freedom, our ideas about what it means for some polity to exhibit justice or fairness toward religious and nonreligious communities and individuals, our evaluation and stance toward power and its exercise, and much else. How we conceive these things determines what it looks like to pursue and enact religious freedom, what we can expect and hope for, and how we judge those efforts. One consequence of this is that there are a great many importantly different things that might be called religious freedom. Any critique must take that into account. 
The new genealogy shares with its foe-call it foundationalism-similar views concerning what religious freedom is. They disagree fundamentally about religious freedom's coherence, ethical character, consequences, and whether it should be pursued. But they agree concerning what comprises it. That agreement makes their conflict possible. It also makes it irresolvable. Each can point to the other's weaknesses. Neither can acknowledge or explain, let alone inherit, the other's strengths. The strengths and weaknesses alike belong to the basic view of religious freedom they share. So long as that view remains unquestioned, the conflict will remain intractable.

Conceiving religious freedom differently moves us beyond the impasse. That is what this article begins to do-above all by calling into question the new genealogy's animating assumptions. While taking seriously the problems it rightly identifies with foundationalism, I reject its tendency to identify power with domination, to collapse any distinction between just and unjust rule. I honor the foundationalist commitment to pursuing a real social good worth calling "religious freedom" but conceive of such freedom in a very different way. My vision is pragmatic, meliorist, dialectical, and democratic. Discarding the notions of neutrality, freedom, power, and religion that lock the parties in conflict, I briefly sketch alternate conceptions of each.

While I can only outline this vision, doing so displays its difference from the paradigm that foundationalism and new genealogy share. Foundationalism and the new genealogy do not exhaust our alternatives. Realizing this renders optional what can seem inevitable. We can inherit the strengths of both views while avoiding their weaknesses. That is what this dialectical vision does.

What I identify here as the new genealogy of religious freedom is an ideal type derived from various interconnected claims and commitments that have recently found expression across a range of disciplines - from religious studies and law to anthropology and political science. It represents my effort to put these pieces in order, trace their connections, and discern their trajectory, rendering whole, explicit, and intelligible a theoretical stance and set of criticisms currently in the air. I aim to clarify just what this position amounts to, untangle the relations among its elements, identify the underlying assumptions, and scrutinize all this for consistency and adequacy.

Since the claims come from various sources, the type should not be assigned to any one text, let alone any single figure. Nor should we assume agreement among the various texts and figures cited. Indeed, it is no part of my aim to adjudicate who might or might not count as a new genealogist and in what sense. But whether anyone fits the type or not, the claims demand attention. ${ }^{\mathrm{I}}$

I Usually, an ideal type abstracts quite significantly from whatever subject or phenomena the type is intended to stand for. It picks out and arranges salient features that seem common to a data set, elevating some, suppressing others, in order to pursue inquiry. But it does not suppose that any particular member of the set corresponds to or realizes all of the features in question, nor even that the data set is linked or bounded in the ways the type might suggest. My approach shares with this common one some degree of abstraction so that it is left open whether any individual or group actually realizes all the salient features or realizes them in the way the type suggests. It differs from many constructs of ideal types, however, in deriving almost entirely from some of the testimony of concrete individuals and groups and, by engaging in detail with that testimony, in trying to discern and elucidate some of its structure and content in order to fill out the type. In that sense, it does not represent as radical of a departure or as extreme of an abstraction as do many ideal types. Notably, several recent articles have argued that one or another of the figures on whose remarks I draw in constructing my ideal type are in fact best interpreted as endorsing one or another commitment I associate with the new genealogy of religious freedom type. See, for example, Jason Springs, "Tentacles of the Leviathan? Nationalism, Islamophobia, and the Insufficiency-yet-Indispensability of Human Rights for Religious Freedom in Contemporary Europe," Journal of the American Academy of Religion 84, no. 4 (2016), 903-36; Vincent Lloyd, "Religious Freedom is Bad," Syndicate, November 28, 20I6, https://syndicate.network/ symposia_commentary/beyond-religious-freedom/; and, especially, Joshua T. Mauldin, "Contesting Religious 
Often rhetorically striking, sometimes prophetic, these remarks echo beyond their diverse contexts and even counter-claims they sometimes dwell beside. They take on a life of their own. Particularly given the prominent collaborative efforts that give rise to many of them, the impression of an integrated theoretical vision can be difficult to resist. ${ }^{2}$ And the impression alone is enough to shape conversations and communities, scholarship and statecraft. I aim to bring this vision into focus, to identify the stance, convictions, and assumptions these claims seem to express, and to subject all of this to scrutiny.

This article critiques the new genealogy on the basis of commitments and issues internal to its paradigm and evident in its theory and practice. ${ }^{3}$ As such, it is a form of immanent critique. The critique advances the case for my alternative - not merely by showing the new genealogy untenable but by showing how the new genealogy itself implicitly depends on a vision like the one I offer. As critique, new genealogy itself is not coherent without a wholehearted commitment to freedom as non-domination. Absent such a commitment, it devolves into self-contradiction or nihilism.

In criticizing the new genealogy, I do not mean to aid its foundationalist rival. The search for foundations - in New Natural Law, in pure practical reason, or behind a veil of ignorance-is a quest for a universal solution to challenges of difference. It "solves" such challenges by disappearing difference under a veil that denies its own partiality and historicity. ${ }^{4}$ Unmasking injustice and

Freedom: Impossibility, Normativity, and Justice," Oxford Journal of Law and Religion 5, no. 3 (2016): 457-8I. Mauldin's article, which addresses Winnifred Fallers Sullivan's influential book The Impossibility of Religious Freedom (Princeton: Princeton University Press, 2005), shows the kind of very detailed, fine-grained interpretive work that would be necessary at each point in order to establish where just one of these figures in one of these texts is best understood as standing on one of these issues. This article remains agnostic as to which of the commitments and criticisms, if any, the figures on whose remarks I draw mean to endorse. In constructing the type and mapping the connections, entailments, and presuppositions among the various strands of criticism that appear in these texts, one thing I hope is that the figures who have penned the remarks I draw upon to construct the type would tell us more explicitly and clearly just where exactly they stand on the various claims their works seem to express. From the package of views that comprise the ideal type, which claims and criticisms, if any, in what senses, and in what combinations does each of those figures associated with this movement mean to endorse? Clarity on that question would do much to help advance the conversation their work has helped provoke.

2 One important collaborative effort is the Politics of Religious Freedom Project, a multiyear research project supported by a $\$ 496,000$ grant from the Henry Luce Foundation and led by Elizabeth Shakman Hurd, Winnifred Fallers Sullivan, Saba Mahmood, and Peter Danchin. With nearly half a million dollars from Luce alone, institutional support from University of California, Berkley, Northwestern University, and Indiana University, graduate interns, international conferences, development of undergraduate and graduate syllabi to shape teaching, and works of scholarship, from edited volumes to special journal issues to monographs, that project represents a major, highly visible multipronged research agenda. See, for example, "Grant Spotlight: The Politics of Religious Freedom," Henry Luce Foundation, http:/www.hluce.org/prfspotlight.aspx; "Grant Archives-Religion \& International Affairs 2010,” Henry Luce Foundation, http://www.hluce.org/archives_grants.aspx?page=hrli\& year=20Iо; and "About," The Politics of Religious Freedom, http://politics-of-religious-freedom.berkeley.edu/.

3 As I have above, I often call the new genealogy of religious freedom simply "the new genealogy." Later, I also use that phrase to refer to a broader phenomenon. Context indicates the intended usage.

4 Representative foundationalists include Kant, Locke, John Rawls, and John Finnis. For our purposes, what links these and other figures is the shared quest to resolve challenges of diversity by appeal to universalist or universally validated principles (often closely linked to or even identified with $\mathrm{R} /$ reason), such as contract theory (for example, Kant, Locke, and Rawls), natural law (such as Finnis), aesthetics, utility, or others.

Foundationalist motifs are exemplified in the following remarks. Robert Audi insists that law must

be supported by citizens independently of what they happen to approve of politically, religiously, or ... morally. ... [W]e should ... separate religion from law and public policy ... [O]ne has a prima facie obligation not to advocate or support any law ... that restricts human conduct unless one has, and is willing to offer, adequate secular reason .... A secular reason is roughly one whose normative force does not evidentially depend on the 
oppression-especially when those operate under the guise of freedom-is vital. Any satisfactory account of religious freedom must attend to this reality. Doing that represents the new genealogy's greatest contribution. Doing only that represents its greatest weakness.

There are other forces at work in history and community than one or another face of ressentiment, the will to power, or lust for domination. There is mutual recognition; just pursuit of just ends; principled, critical intelligence; creative resistance; just efforts to render power relations equitable, accountable, and nonarbitrary; friendship; and even love. Were that not so the new genealogy itself could only be another power play. It certainly could not criticize others for being driven by the very forces that necessarily animate its own efforts. Any vision of religious freedom must be no less attentive to the realities and possibilities of justice, mutual recognition, and freedom than to the dark forces the new genealogy reveals. That such ideals are authentic and sometimes imperfectly realized is why one ought to pursue religious freedom-or even critique-in the first place. ${ }^{5}$ In

existence of God or on theological considerations ... [O]ne also has ... to abstain from such advocacy ... unless one is sufficiently motivated by adequate secular reason.

"The Place of Religious Argument in a Free and Democratic Society," San Diego Law Review 30, no. 4 (I993): 677-702, at 690-92.

Stephen Macedo claims that

Locke recognized that ... the soul and religion need to be shaped in accordance with political imperatives.... Creating a certain religious homogeneity ... is crucial and legitimate political work that liberals must hope is performed.

Proponents of greater solicitude for religious minorities could cripple the subtle and indirect means of turning religious and other systems of private belief in directions that support the regime.

"Transformative Constitutionalism and the Case of Religion: Defending the Moderate Hegemony of Liberalism," Political Theory 26, no. I (I998): 56-80, at 64-65, 70 . And Suzanna Sherry declares,

The most basic tenets of each religion tend to be supported primarily by faith rather than reason, and indeed few religious claims could be justified by observation and rational argument. There is thus a difference between religious motivations - which may cause us to believe or feel strongly about particular conclusions that are also rationally justifiable - and an epistemology of faith, in which nonrational beliefs are permitted to trump ordinary rationality. It is only the latter that presents a conflict with reason.

"Enlightening the Religion Clauses," Journal of Contemporary Legal Issues, no. 7 (I996): 473-95, at 478.

5 As mentioned above, this article pursues immanent critique. What is important for our purposes is that it represents a commitment to critique that preserves Kant's insistence on taking critical, rational inventory of the very workings of rationality, including the concepts with which we think and by which we structure our lives and communities, while dispensing with his pursuit of transcendental foundations for that project-and so for politics, ethics, and rationality itself. Arguably, John Rawls, Jurgen Habermas, and their followers carry forward both of these prongs of the Kantian project. Speaking roughly, immanent critique, in contrast, maintains the Kantian commitments to rationality and critique but revises the underlying vision of rationality in a non-transcendental and (in the case of the particular brand pursued here) social-practical direction. According to the immanent critic, we can do no other-or better-than to begin from where we and others are, which could always be other than it is, and on the basis of commitments, practices, and values we or others already endorse or consider endorsing. Rather than seeking criteria or standards that "no reasonable person could reasonably reject" on the basis of which to undertake critique or trying to bracket all the commitments we actually have, we critically assess and engage the values, commitments, institutions, and practices we, our interlocutors, or both of us accept or are considering accepting and we do so on the basis of what is implicit in the very commitments and values in question, or in light of still others known to be endorsed. On this vision, in pursuing such critical assessment, we can never step onto some basis 
fact, the methodology and critique of the new genealogy of religious freedom depends on this very point for its force and coherence.

\section{SKETCHING THE NEW GENEALOGY OF RELIGIOUS FREEDOM}

The new genealogy of religious freedom is marked above all by five basic, closely interconnected charges against religious freedom. These criticisms are directed not at one or another variety of religious freedom but at religious freedom as such:

Criticism I. The incoherence criticism: Religious freedom is "impossible," viciously paradoxical, a contradiction in terms, inherently unstable, "pretend," a fantasy, and so on. ${ }^{6}$ Its pursuit is incoherent and self-contradictory.

Criticism 2. The systemic bias criticism: Religious freedom is inevitably and systematically biased against minorities, the disempowered, non-Christians, and any whose "religion" is not liberal Protestantism. Presupposing a host of procrustean dualisms-belief/practice, inner/outer, sincerity/ritual, individual/community, private/public, elite/lived, Western/Eastern, Christian/nonChristian-and always privileging the former, it disproportionately oppresses the disempowered, those outside the "mainstream" of their traditions, or those whose religion differs from liberal Protestantism.7 A "majoritarian" tool of "minoritization" (JLR, 359) and a form of "transvalued Christianity" (SAQ, 4$)^{8}$ "again and again it passes off an inevitably partisan narrative as a universal one" (PRF, IO2).9

Criticism 3. The tool of oppression criticism: Religious freedom is oppressive, a tool of neocolonialism and imperialism (JLR, 362). "Deeply and problematically connected to a politics of fear" (PRF, 232), it is "an instrument of raison d'état" (SAQ, 6). "An operation of modern secular

that is itself immune to challenge or untouched by history and contingency but instead always depend on at least some values and practices that are open to correction and criticism and touched by history and contingency. Yet we can consider and assess strictly all of these values and practices piecemeal and in turn, just not all at once, presupposing as we go commitment to some values (even if only in a hypothetical mode), which, in turn, we can subject to scrutiny on the basis of other values and so on. On this view, to take leave of the quest for foundations is not to take leave of rationality or critique-or of the important distinctions critique would draw between such things as just and unjust social arrangements and power differentials. This is worth spelling out because the mode of critique this article pursues itself mirrors the positive proposal I briefly sketch.

6 Winnifred Fallers Sullivan, The Impossibility of Religious Freedom (Princeton: Princeton University Press, 2005), I (hereafter IRF); Winnifred Fallers Sullivan et al., eds., Politics of Religious Freedom (Chicago: University of Chicago Press, 20I 5), 8 (hereafter PRF); Elizabeth Shakman Hurd, Beyond Religious Freedom: The New Global Politics of Religion (Princeton: Princeton University Press, 20I 5), 6, I 5 , I I I , and I I I (hereafter BRF). Henceforth, these texts are principally cited parenthetically in text, along with the following: Winnifred Fallers Sullivan and Elizabeth Shakman Hurd, "Editor's Introduction," Journal of Law and Religion 29, no. 3 (2014): 358-62 (hereafter JLR); Saba Mahmood and Peter Danchin, "Politics of Religious Freedom: Contested Genealogies," in "Politics of Religious Freedom: Contested Genealogies,” ed. Saba Mahmood and Peter G. Danchin, special issue, South Atlantic Quarterly II3, no. I (20I4): I-8 (hereafter SAQ). "The state's sovereign power to define and regulate religious life," Mahmood claims elsewhere, "is shot through with a generative contradiction." Religious Difference in a Secular Age: A Minority Report (Princeton: Princeton University Press, 2015), 3.

7 See, for example, PRF, 7, and BRF, I3.

8 Danchin and Mahmood are here quoting approvingly from an essay in their edited special issue: Nehal Bhuta, "Two Concepts of Religious Freedom in the European Court of Human Rights," in "Politics of Religious Freedom: Contested Genealogies,” ed. Saba Mahmood and Peter G. Danchin, special issue, South Atlantic Quarterly II3, no. I (2OI4): 9-35, at 20.

9 See also BRF, $53-54$. 
power [that] generat[es] new forms of religious prejudice and enhance[es] old ones" (SAQ, 6) while "hardening existing lines of religious difference" (SAQ, 7), religious freedom serves not only to subjugate but actually causes the disease it claims to cure. It creates-then worsensthe very divisions, persecution, and violence it purports to heal.

Criticism 4. The ideology criticism: Religious freedom is a statist tool for "mind control" (PRF, I4, 55). It not only conceals its oppressive character but presents itself as securing liberation. "At times ... intentionally duplicitous" (PRF, 9), it "facilitates the hegemony of powerful geopolitical actors [and] generate[s] new political polarizations" (PRF, 7). Posing as an instrument of liberation, it wins endorsement from those it subjugates-while obfuscating this from its victims. It is ideology par excellence.

The fifth criticism underlies and unites these four:

Criticism 5. The essentialist criticism: All of these flaws are intrinsic to religious freedom. It is essentially like this. "In adjudicating any claim to religious liberty, judges are trapped ... in ... the modern panopticon of Enlightenment rationality ... a fraught but familiar dialectic of power and illusion" (my emphasis, PRF, 245). "All religious freedom cases" can be read in this way (PRF, 245). Religious liberty "is a technique of ... governance whose proper exercise has always entailed concerns of realpolitik" (my emphasis, PRF, I45). Vitally, "none of this is a corruption of the right to religious liberty ... [but due to] an antinomy ... internal to the right itself" (SAQ, 5). Such problems are not the "cynical instrumentalization of an otherwise noble principle... [but] reflective of the contradictions and paradoxes internal to the conceptual architecture of the right to religious liberty itself" (my emphasis, PRF, I47). These pathologies of religious freedom are not due to abuse of religious freedom but are entailed by and constitutive of it. They "inhere in the logic and practice of [religious freedom] and cannot be transcended by adopting a more informed understanding of contemporary religion or a more effective regime of rights implementation" (my emphasis, BRF, 54). ${ }^{\mathrm{IO}}$ Incoherence, bias, oppression, and ideology are inescapable for they inhere in the "essence" of religious freedom. ${ }^{\text {II }}$

But with the essentialist criticism, the new genealogy of religious freedom presupposes something. Indeed, the five criticisms, individually and taken together, depend on a fundamental assumption:

Assumption I. The very idea of religious freedom: All these criticisms are taken to obtain to religious freedom as such. They are claims about what religious freedom is and must be. This is not only explicitly stated, it is implied every time religious freedom is criticized in an indiscriminate or general way, whenever claims are made about "religious freedom," "the right," or "the concept," without further qualification - which is almost the only way that the new genealogy criticizes religious freedom. ${ }^{\mathrm{I} 2}$ Either way, this presupposes that there is such a thing as the

Io And see BRF, 6, 58-59, 63, I2I.

I I This criticism both makes explicit what is implied in the first four criticisms, insofar as they are almost exclusively directed at religious freedom as such or claim something about what religious freedom essentially or inevitably is or must be; and names the new genealogy's explicitly modal or essentialist claims. Due to the former dimension, the focus on religious freedom as such, this fifth criticism would remain even in the absence of these latter explicit formulations concerning religious freedom's essence and the like. Eliminating the fifth criticism from the new genealogy of religious freedom would require the movement to reformulate all the other criticisms.

I2 The five criticisms implicate the assumption in addressing religious freedom as such, generally, or without qualification, but the first makes not only a universalist and essentialist claim but an explicit claim about what can 
very idea of religious freedom, some singular, unified thing that is religious freedom as such, some essence common to every variety. But it is one thing for some religious freedom regime or conception to suffer these flaws or even for such flaws to inhere in some particular conception. It is another thing altogether to think these flaws inhere in religious freedom as such, that they are intrinsic to any possible conception. That is just what these criticisms presuppose and claim. "The very idea of freedom of religion is paradoxical" (my emphasis, PRF, 298). Certain pathologies are "intrinsic to the modern understanding of [religious freedom]" (my emphasis, PRF, I7-I8), "inescapable" thanks to "the structure of the modern liberal state." ${ }_{3}$ "The concept of religious liberty" has a "bifurcated nature" (my emphasis, SAQ, 3). "Contradictions and paradoxes ... lie at the foundation of this much-coveted right" (PRF, I43). There's not only a single, essentialized right; this right has a "foundation." ${ }_{4}$

and cannot possibly be. And explicitly claiming that the first four criticisms are inevitable, the fifth criticism presupposes "the very idea" in an especially obvious way.

I3 Mahmood, Religious Difference, 2 (my emphasis).

I4 There is also "The idea of conscience" (PRF, 60) and "the idea of the religiously free state" (PRF, 333), along with "modern secular power" which has "the distinguishing feature" of birthing religion-related "dilemmas" (BRF, II). The very idea of "a right" necessarily presupposes individualism and the state: "The idea of a right to religious freedom ... the notion of 'a right' implies a relation between the state and an individual legal subject" (my emphasis, PRF, I73; see also PRF, 25, 333, 290, 228; BRF, 39). "The modern state" has "its political rationality" - which transforms and polarizes religionists. "The liberal state claims to maintain a separation between church and state by relegating religion to the private sphere," and this is part of "the liberal state's ideological commitment," and all of this is part of "the secular project." Mahmood, Religious Difference, 2, 4. "Secularism characterizes all modern societies ... in the institution of the liberal state, its laws, and its strategies of governance, making it a necessary feature of modern political rationality. The right to religious liberty, the legal distinction between public and private, the concept of public order ... are all elements of this political rationality" (Mahmood, 208, my emphasis; see also 2 I-23, 9). "The very concept of the nation-state" and "the modern state" ground claims of "structural prejudice built into the modern state": "the very concept of the nation-state ... necessarily privileges majoritarian beliefs, practices, and cultural values" (my emphasis, PRF, 266). "The secular state is necessarily involved in regulating the social life of religion and often prescribing substantive content while ... claiming to treat all of its citizens equally" (PRF, 6). Those with exegetical aims would need to square all this essentializing talk with claims that, for example, "it is a mistake to conceive of religious liberty as a single, stable principle" (PRF, I73; see also JLR, 359). Of a piece with new genealogy's essentialized views of religious freedom and "the state" or "the liberal/modern state" is the assumption of an essential connection between religious freedom and the state. At the very least the new genealogy's critiques, claims, and assumptions about religious freedom detailed above (for example, in the five criticisms and four assumptions) assume and target "religious-freedom-as-purveyed-by-the-state" (or "-the-liberal-state" or "-the-modern-state"), whether or not they are also meant to apply to religious freedom as implemented by non-state polities or whether the new genealogy imagines that anything sponsored by a non-state entity should even be called "religious freedom." In other words, when the new genealogy talks about religious freedom-issuing its critique, making these assumptions -it always at least refers to religious freedom as implemented by "the state," whatever it would want to say about religious freedom as disentangled from "the state" (if it even could be so disentangled). One way to respond to the new genealogy of religious freedom would be to attempt to disentangle religious freedom from state sponsorship and to grant that state-sponsored religious freedom is just as the new genealogy of religious freedom says while arguing that religious freedom is not essentially tied to state action and that, when loosed, escapes the new genealogy's criticisms. That is not the strategy pursued here. Instead, I meet the new genealogy of religious freedom on its own ground by granting its linkage of religious freedom with state action and focusing exclusively on religious-freedom-as-pursued-by-or-somehow-implicating-states (though not as purveyed by something called "the state," for such essentializing assumptions about "the state" and religious freedom as purveyed by it are among the very flaws that doom the new genealogy of religious freedom's account). For the new genealogy, religious freedom and state power are so deeply intertwined that the two are melded together in its account and critique - and that is the vision to which I respond. So, even leaving entirely in place the new genealogy's conviction that religious freedom is purveyed by and entangled with state action, a commitment baked into its assumptions 
This first assumption, however, is implausible. There is no essence of religious freedom, no such thing as the very idea of it. In principle there are as many possible conceptions of religious freedom as there are conceptions of religion and freedom and as there are diverse ways of wedding these conceptions and seeking to enact them.

This faulty assumption undermines the new genealogy's criticisms. So long as they remain directed at religious freedom as such, generally, or indifferently or otherwise continue to presuppose the very idea of religious freedom, they miss the mark. And even apart from explicitly modal or essentialist language or claims about inevitability, necessity, and the like, so long as the new genealogy's criticisms are directed at "religious freedom," "the right," or "the concept" in an unqualified, unspecified, or general way or invoke "the state," "the secular," and the like, they suffer from - and are undone by - the very idea assumption.

Now, the particular version of religious freedom that new genealogy critiques and identifies with religious freedom as such is actually inherited from its foundationalist opponents. That vision and the new genealogy's criticisms rest on three further assumptions. The new genealogy borrows two, concerning freedom and neutrality, from foundationalism. The last, concerning power, is its own distinctively genealogical contribution: ${ }^{\mathrm{I}}$

Assumption 2. Freedom is noninterference, the capacity to do as one pleases without interference or with as little interference as is compatible with others being similarly free from interference.

Assumption 3. Neutrality is adjudication founded on and expressive of universal Reason, or the like. It rises above history, contingency, and interest, and exclusively deploys principles that no reasonable person could reasonably reject.

Assumption 4. Power is exhaustively pervasive and ethically poisonous, at least in modernity and politics. Power asymmetries, above all those realized by or in "the state," are inherently dominating.

The new genealogy's entire critique presupposes these assumptions. They are essential to any coherence or plausibility the criticisms have. But we need not accept these assumptions. There is certainly no reason to think religious freedom generally is committed to or presupposes them. If we dispense with the assumptions, we dispense with the criticisms. And if the assumptions are unfounded or problematic, we have reason to leave both foundationalism and the new genealogy of religious freedom behind.

In what follows, I show how these assumptions animate and inform the new genealogy's critique and why they are problematic or unfounded. The new genealogy's entire agenda depends on them; it requires that they represent the only possibilities for conceiving religious liberty. They do not.

and critiques, neither those assumptions nor those critiques withstand scrutiny. Precisely religiousfreedom-as-purveyed-by-states need not be what the new genealogy claims it is. Engaging the new genealogy exclusively in relation to religious freedom implicated in state power, I show that even on that vision its assumptions are unfounded, its criticisms only relevant for certain narrow and optional conceptions of religious freedom. We can reject these conceptions: they are not the only ones extant in modernity or available for state implementation. I embrace this approach not only in view of my commitment to immanent critique but because my concern, like the new genealogy of religious freedom's, is with religious freedom as actually and potentially enacted-and, at present, that largely means religious freedom as enacted by and implicating states. If the only versions of religious freedom immune to the new genealogy's critique were ones that did not implicate state activity, that would rescue religious freedom at the price of rendering it largely irrelevant-at least for the foreseeable future.

I5 These assumptions do not correspond to individual criticisms delineated above but jointly animate them all in diverse ways. 
There are alternate ways of imagining freedom, neutrality, power-and religious freedom. I briefly sketch one such way-one that honors the very concerns animating the new genealogy. Yet, whatever one makes of this sketch, the new genealogy's assumptions are problematic on their own terms and hardly exhaust the alternatives. While its criticisms are relatively effective against foundationalist religious freedom, the fundamental problem is its identification of that vision with religious freedom generally, the notion that this exhausts what religious freedom is and must be. But we need not conceive of religious freedom in foundationalist terms.

Entangled in all this too is one final feature of the new genealogy of religious freedom: its genealogical character. Genealogy-in some sense-is what-in some sense-grounds its critique. As the two qualifications suggest, there is murkiness here. The new genealogy of religious freedom describes itself as undertaking genealogy and pursues a quintessentially genealogical critique: unmasking religious freedom's alleged violations of the very values it claims to promote. Yet ambiguities remain. Two stand out. First, it is unclear what the new genealogy of religious freedom's exact relation to genealogy is -in what sense precisely it is genealogical. Secondly, notwithstanding its commitment to unmasking, it is not clear what the relationship is between the new genealogy of religious freedom's brand of genealogy and the criticisms it levies, how precisely genealogy substantiates or supports those. As it turns out, these two issues - the new genealogy of religious freedom's type of genealogy and the relation between that genealogy and the new genealogy of religious freedom's critical agenda-are inextricably intertwined.

So, after considering their assumptions, I identify the kind of genealogy that the new genealogy of religious freedom exemplifies - one situated between historical and Nietzschean genealogy. And I elucidate in what sense this genealogy is suited to the new genealogy of religious freedom's critiqueonly insofar as we understand foundationalist religious freedom alone as its target, and, even then, ill-suited. Most simply, the new genealogy of religious freedom not only falls short of giving us reason to abandon religious freedom, but is itself caught in an unstable and self-consuming stance.

\section{THE NEW GENEALOGY OF RELIGIOUS FREEDOM'S CRITIQUE AND ITS ANIMATING ASSUMPTIONS: FREEDOM, NEUTRALITY, POWER}

In this section, I elucidate and assess the new genealogy of religious freedom by examining three assumptions or themes that undergird its vision and critique of religious freedom: freedom as noninterference; neutrality as expressive of universal Reason; and power as both exhaustively pervasive and ethically objectionable. The success of the new genealogy's critique requires these conceptions of freedom, neutrality, and power be the only on offer. These three conceptions are assumptions in two senses: essential to the critique and taken for granted rather than defended. Each informs and animates the new genealogy's five criticisms in different ways.

\section{Freedom as Noninterference}

The new genealogy and foundationalism alike conceive of freedom in terms of noninterference. Religious freedom is constituted by noninterference in religious matters. Freedom is doing as one pleases, and interference violates freedom. Law, therefore, limits freedom-ideally to preserve more freedom. Religious freedom is a matter of balancing freedom lost with freedom gained, typically while treating some losses, those proscribed by rights, as impermissible. Where foundationalism pursues such freedom, the new genealogy regards it impossible and ideological, noting its bias toward individuals over communities. But both agree that this is what freedom is. 
Consider a remark from Winnifred Fallers Sullivan's The Impossibility of Religious Freedom. This basic view of freedom seems central to why the book regards religious freedom as "impossible":

All freedoms are bounded.... They are only "free" in a manner of speaking, free within a particular political system and given the limitations of that system.... One may not say anything anywhere. One may not print anything. ... Not everyone can vote. The state controls all of these human activities, and does so for its own purposes. So too, with religion. Religion is not limitlessly free in any human society. (IRF, I 55)

Freedom, here, is noninterference. It is "bounded" when the state imposes restrictions, "controls," or interferes. Such interference limits freedom, opposes it. Thus, "religious freedom is not absolute" precisely because it is bounded by regulations (IRF, I 55 ). Limitless freedom-to be free in more than "a manner of speaking" - in contrast, would mean the absence of all interference, the capacity to do whatever one pleased.

This vision of freedom also seems apparent in the book's conception of religion: "It is the peculiar nature of religion itself to restrict freedom" (IRF, I 55 ). This restriction is a matter of "devotion to the rules of [some] religion," "non-negotiable things being demanded of one." ${ }^{6}$ Notice the conception of freedom operative here: religions impose rules and non-negotiable demands, therefore and thereby religions restrict freedom. ${ }^{17}$ Rules necessarily curtail and violate freedom. Freedom, then, consists in noninterference. This is why it is that "to be religious ... is to live without a certain amount of freedom" (emphasis in original, IRF, I 56). This is why "to be religious is not to be free" (my emphasis). "To be free," Sullivan remarks, "is today understood to mean to have the ability to choose for oneself in all areas of life without restraint" (IRF, I 56). A clearer articulation of freedom as noninterference would be hard to find. ${ }^{18}$

The new genealogy, for its part, assumes freedom is noninterference and that this represents the ideology of modernity, secularity, and liberalism. The critique is familiar: Freedom dichotomizes belief and practice, making belief the zone of noninterference, claiming all else for itself. It is hyperindividualistic, positing an atomistic, autonomous self for whom communities and commitments degrade freedom. Religious freedom "is articulated, through ... liberal rights, as a set of discrete freedoms claimed by autonomous units (individuals or groups) from an assumedly neutral state" (JLR, 36I). "Individual conscious and belief as the proper locus of religion" are intrinsic to "the modern conception of religious liberty" (PRF, I43). Indeed, "liberal individualist notion[s make] the modern conception of freedom of [religion] possible" (PRF, I43). Such "individual rights" are one part of "the modern nation-state['s]" "aim to transform political difference into sameness" (PRF, I 43). Most simply, "religious freedom ... is built around a particular notion of the 'free' ... human" (PRF, 5I). And this "human of secular liberalism," "the subject of religious freedom is an

I6 "Fiercely religious persons ... are those with an unbending devotion to the rules of their religion .... [Those who] seem to live in a world ... in which certain non-negotiable things are demanded of one" (IRF, I 55 ).

I7 One might wonder about the notion that religion is unique in imposing unconditional demands, for any number of communities and roles seem to carry all sorts of duties and unconditional demands. Being a friend, parent, teacher, coach, child, spouse, or citizen might be understood to impose demands that, so long as we wish to occupy that role (or occupy it well), are unconditional.

I 8 For Michael Lambek, "What religion is not is freedom. Hence, the very idea of freedom of religion is paradoxical; it is the freedom to be unfree" (PRF, 298). This version of the incoherence criticism (that is, religious freedom is unfree) is distinct from another version which is rooted in alleged antimony between the governmental neutrality the right guarantees and the interference and bias it authorizes (see, for example, SAQ, 3-4 and 6-7; PRF, I77). It seems to trade on both an essentialist view of religion and a vision of freedom as noninterference. 
autonomous individual defined by his or her freedom to choose to believe or not" (PRF, $5 \mathrm{I}$ ). ${ }^{\mathrm{I} 9}$ The new genealogy equates freedom with hyper-individualistic liberal autonomy. ${ }^{20}$

If this is what religious freedom means, no wonder the new genealogy rejects it. This noninterference vision grounds criticisms related to freedom and neutrality alike. I consider neutralityrelated critiques shortly; those concerning freedom first. These chiefly concern the new genealogy's claim that religious freedom is impossible or incoherent but also bear directly on its other four criticisms. Religious freedom purports to offer freedom, noninterference, but actually involves the state in all sorts of interference. Religious freedom is thus inherently unattainable because always limited. Further, it inevitably involves governmental interference, even if only in the legislation, adjudication, and scrutiny that pursuit of religious freedom involves.

More fundamentally, the necessity of defining religion constitutes profound unfreedom. The question and adjudication of what counts as religion involves ongoing, obvious, and pervasive interference-freedom's antithesis. And, such judgments, the new genealogy says, are anything but neutral: "The right to religious liberty authorizes the state to intervene in what appears to be mere expressions of religious belief but in fact involves the state in making substantive judgments about religion, a domain toward which it claims to be neutral. ... [Religious liberty] maintains that religious belief is immune from intervention [that is, free] while at the same time sanctioning its outward expression." ${ }^{21}$ Religious freedom requires that religion be defined in some way but this involves interference, and "Who decides? Who decides what counts as a [religion] deserving of special protection and legal exemption rather than as some other [thing]" (PRF, 5I)? ${ }^{22}$ The state decides, of course, and insofar as the state decides, the state interferes, violating freedom. "As Talal Asad has argued, the very acts of ... legal systems have constituted ['religion'], demarcated certain practices and institutions as religious, and recognized specific tokens as religions. Hence both the general nature of 'religion' ... and the recognition of specific 'religions' ... are objects of the legal gaze" (PRF, 289). Religious freedom is thus birthed in and perpetuates unfreedom. The state or "the secular is always entangled with the religious" (PRF, 210). Religious freedom, therefore, is necessarily interference and unfreedom all the way down: "religious freedom ...necessarily involve a dividing of legal religion from illegal religion-good religion from bad religion ... along an ongoing set of dichotomies ... individual or communal, private or public, spiritual or material, belief or practice, chosen or given, Protestant or Catholic, Western or Eastern, peaceful or violent, utopian or locative, universal or particular" (PRF, 7). This is religious freedom as ideology, promising one thing; giving the contrary. It is a tool by which religion is "tamed to fit the

I9 For the new genealogy of religious freedom, cordoning off "private belief" from public, practical, or bodily realms is part of the state's strategy of control. It is also a direct consequence of a conception of freedom as noninterference, for belief gets defined as immune to interference and thus free. Having defined religion as belief and declared belief beyond governmental interference, one can claim to honor religious freedom even as one interferes maximally at the level of practice (See, for example, PRF, 3, 48, 243, and 246; BRF, 58-59). Note as well the essentialism running through the remarks above.

20 And, as we have seen, it also tends to see religion itself as essentially a realm of unfreedom and this in virtue of religion's alleged character as interfering in human conduct and community or restricting choice.

2I Saba Mahmood and Peter G. Danchin, "Immunity or Regulation? Antinomies of Religious Freedom," in "Politics of Religious Freedom: Contested Genealogies," ed. Saba Mahmood and Peter G. Danchin, special issue, South Atlantic Quarterly II3, no. I (2014): I 29-59, at I 29-30.

22 Elizabeth Shakman Hurd here couches the claim in terms of "religious belief" rather than "religion," but the essay's force is that religion and religious freedom have been reduced to belief. 
requirements of law" (JLR, 362). ${ }^{23}$ It is a regime of oppression and unfreedom. And this is so, in large part, because following its foundationalist opponents, the new genealogy identifies freedom with noninterference.

\section{Neutrality as Ideological, Impossible, and Inevitably Biased}

We have already begun to see the new genealogy's second key assumption: a utopian, "God's-eye view" conception of neutrality borrowed from its foundationalist opponents. Religious freedom must arise from and express principles that are "Neutral," in the sense of being universal, unassailable deliverances of Reason, natural law, freestanding political conceptions, and the like. The new genealogy of religious freedom regards such Neutrality as a fiction, and effectively shows how it implicates all sorts of controversial normative stances. Yet, it imagines that, either singly or jointly, (I) the impossibility of this sort of neutrality along with (2) particular legal cases that display prejudice, show that religious freedom can only be sheer partiality and bias. Collapsing principled evenhandedness into foundationalist Neutrality, the new genealogy mistakenly imagines that Neutrality's bankruptcy means that evenhandedness is impossible or that it is no different from bias or caprice.

The Neutrality assumption animates the new genealogy's critique in two ways. First, religious freedom is not Neutral because it involves pronouncing on substantive matters concerning what constitutes religion and in that and other ways taking sides in religious disputes. Yet such matters are highly contestable, and there is no value-free grounds or "view from nowhere" from whence to resolve them. Why should a court's view count as Reason's deliverance any more than some disputant's view? Strictly every decision unfolds from some contingent position and context, a court's or government's no less than some religionist's. Thus, Neutrality-and so religious liberty-are a sham.

Second, religious freedom not only fails to be Neutral, it is inherently and radically biased in particular ways. Recall: "religious freedom ... necessarily involve[s] a dividing of legal ... from illegal religion-good religion from bad ... along an ongoing set of ... dichotomies ... individual or communal, private or public, spiritual or material, belief or practice, chosen or given, Protestant or Catholic, Western or Eastern, peaceful or violent, utopian or locative, universal or particular" (my emphasis, PRF 7). The former of each pair here is "good" religion, what religious freedom privileges: belief over practice, individual over community, Christian over non-Christian, soul over body, elite over lived, majority over minority. ${ }^{24}$ If this were so, religious freedom would not simply fail to attain the mirage that is Neutrality, it would fail to be fair or evenhanded in any sense at all, much less any sense worth caring about.

Grant that religious freedom sometimes exhibits such bias. ${ }^{25}$ Yet the new genealogy insists this is all it ever can do: “'Religious freedom' ... is ... partial and contingent, often discriminatory, always

23 "Religious lives and possibilities are being legally tailored ... to meet the global demand for tolerant religious subjects" (BRF, 5). Religious freedom is a "technique of governance" (BRF, I7). And see BRF, I6, 5, I I, 38, I I I, and, on ideology/freedom linkage, 6r; Mahmood, Religious Difference, 60.

24 "In ... promoting religious freedom, specific forms of religion, certain religious leaders, and particular religious traditions are inevitably singled out ... . That which is singled out is privileged and consecrated through legal and political advocacy and guarantees for freedom, rights, and toleration. It often does not align with-and may sideline or crush-disparate, improvised forms of religious belonging and practice. Dissidents, doubters, and those who identify with nonorthodox versions of protected traditions struggle for representation" (BRF, I3). See also BRF, xii, I8, 58-59, and 63 .

25 I do not pursue the distinct neutrality-related question of singling out religion for protection vis-à-vis nonreligious conscience claims. See, for example, Andrew Koppelman, Defending American Religious Neutrality (Cambridge, 
partisan" (my emphasis, PRF, I03); "Again and again it passes off an inevitably partisan narrative as a universal one" (PRF, IO2); "No secular state is or can be merely neutral or impartial among religions, for the State defines the boundaries within which neutrality must operate" (my emphasis, PRF, I67). Indeed, "the secular state ... is a distinctive kind of theological state" (PRF, 333). While considering only scattered cases, it pronounces not merely on those cases but, in modal and essentialist terms, on religious freedom as such: it is necessarily and essentially biased.

There are two discernible grounds for these claims: historical and conceptual. Neither withstands scrutiny.

Consider the historical grounds: the genealogically suspicious reading of some legal case(s). Logically, no analysis of a few cases, however much bias they display, could tell us that religious liberty is essentially or necessarily biased. Imagine we could examine every religious freedom case in history and unanimously agree that all exhibited the biases the new genealogists claim. Even in this religious freedom wasteland, the new genealogy's conclusion would not stand, for it would remain entirely possible both that (a) all of the failures had to do with the actors in question, not the guiding principles or conceptions of religious freedom, and (b) that an even slightly revised vision of religious freedom, let alone a more radically reimagined conception, might generate different results. To approach the conclusion that religious freedom is inherently biased based on empirical evidence or historical analysis, our data set would have to include the attempt to actualize every possible conception of religious freedom and have each of them confronted with every possible case.

This is very far from what the new genealogy of religious freedom has shown. Not only has it surveyed only a handful of extant religious liberty cases, and not only is there little consensus concerning even all of those it has considered, but many insightful and learned scholars believe that religious freedom has sometimes been honored in ways not expressive of the biases that the new genealogy claims inhere in the concept. Further, the cases the new genealogy does consider seem chosen and interpreted with the aim of showing that religious freedom is inherently biased. There is nothing wrong with choosing cases to substantiate one's claims, but it is something else to suppose such cases tell us what religious freedom necessarily or essentially is. Given that when it comes to religious freedom we are imagining how we might order our political communities, deploying strategies and ideals that, at least to some degree, are ours to shape, revise, reimagine, and mold to our interests, I doubt religious freedom is necessarily or essentially anything.

This brings us to its second grounds, the alleged "architecture" or logic of the concept religious freedom (or religion). Due to the concept's alleged origins and the suspect ends it has served, the concept necessarily embeds and entails commitments to problematic principles like "Enlightenment Reason," "Kantian autonomy," "panoptical surveillance," "Christianity as best religion," "religion as belief," "religion as dangerous unless privatized." These (alleged) facts about the concept's origin and history mean its ongoing use necessarily perpetuates the bias and violence present from its inception. ${ }^{26}$ So the new genealogy claims. But this is mistaken.

Take any genealogy you like. The fact that a concept has some unsavory history does not entail that all contemporary usage extends or implicates that history. Here we need to begin with a basic logical point and consider first a mundane example before moving to cases with higher stakes.

MA: Harvard University Press, 20I3); Brian Leiter, Why Tolerate Religion? (Princeton: Princeton University Press, 20I2); Cécile Laborde, "Religion in the Law: The Disaggregation Approach," Law and Philosophy 34, no. 6 (20I5): $58 \mathrm{I}-600$.

26 "Religion ... has a history. To invoke religious rights or religious freedom is also to invoke the history of the category of religion, including its long and complex genealogy" (BRF, I2 I-22). 
Many use the "cc" feature in emailing. That practice and concept initially arose in reference to carbon paper. Today, many do not know what carbon paper is or even that $c c$ abbreviates (or once abbreviated) "carbon copy." ${ }^{27}$ Their use of the concept does not express bias toward carbon paper over against other media, nor anything of the sort. That some concept has a history, even an ethically suspect history, does not by itself tell us that ongoing use of the concept perpetuates that history. The broader logical point is just that: for any concept or practice $\mathrm{C}$, that $\mathrm{C}$ arose in some circumstance or has some history does not in itself entail that contemporary deployment of $\mathrm{C}$ perpetuates or entangles one in that origin or those circumstances. To think otherwise is a form of the genetic fallacy.

Certainly, some concepts $d o$ advance histories of oppression - and those histories may be difficult or nearly impossible to avoid extending, even if their users try. Many racial slurs are like this. The racist who uses the "n-word" or the gay-basher who uses "queer" extends the concept's poisonous legacy by carrying on in ways saliently like certain precedent usages. The user here intends to and does use the concept in ways that stand in continuity with these precedent usages. Yet even these maximally toxic concepts can undergo the transformation we call resignification. They can come to take on new valences that are not only other than those associated with prior usages but even directly opposed to them. Thus, a gay man who proudly describes himself as "queer" is neither allying with gay-bashers nor engaged in self-hate. Though this is just what we would have to think if we fell prey to the genetic fallacy and imagined that the history of some concept entailed that contemporary deployments perpetuated or entangled its user in that history. On the contrary, he is deploying a vitally distinct conception as compared to the bigot-the two conceptions are applied to the same people (namely, homosexuals). They share a common circumstance of application, picking out the same group of people. But the consequences that application licenses, the ways of relating and thinking about that to which it is applied, are profoundly different: the one authorizes and enacts abuse; the other, celebration and pride. ${ }^{28}$ That a term as hateful as "queer" was (and often still is) admits of such profound transformation and such distinct senses in such a short time, suggests something about just how much change concepts can undergo and just how many more-or-less related senses or conceptions may develop. ${ }^{29}$

Suppose a concept's meaning is constituted by its circumstances and consequences of application -the circumstances under which it is appropriate to deploy it and the practical or intellectual consequences that follow upon its use, what its application authorizes. Insofar as one or either of these undergoes change, the concept's meaning changes. If the changes become sufficiently significant, we can identify distinct concepts (or distinct senses/conceptions). So, a single term or concept-like queer, chair, religion, or religious freedom-may have multiple senses/conceptions. Even if one or more of these conceptions does carry forward problematic features of some problematic

27 I owe this example to Stephen Bush, Visions of Religion: Experience, Meaning, and Power (New York: Oxford University Press, 2004), I7.

28 This understanding of concepts is rooted in Michael Dummett, Frege: Philosophy of Language (Cambridge, MA: Harvard University Press, I99I).

29 For example, controversies surrounding the use of the "n-word" by black hip-hop artists who (try to) use it with positive valences to signify solidarity, respect, care, brotherhood, and the like are, in part, debates about the success or possibility of resignifying that word. To the extent that such efforts fail, that testifies to the extent to which widespread resignification for some concepts, and perhaps slurs especially, comes only with much effort and time, if at all. Yet, even with that profoundly poisonous term, at least within some contexts, those efforts have been successful to some degree-as witnessed precisely by the practices in question and the very presence of a debate at all. 
ancestral use, it hardly follows that all extant usages or senses do. It certainly does not when one is clear what conception one is using and explicitly rejects problematic ones. $3^{\circ}$

While I find the genealogies of religion on which the new genealogy draws altogether unpersuasive in virtue of neglecting major swaths of history and many of modernity's most important social movements (such as abolitionism, women's suffrage, or India's movement for independence), my point is that even if we accept whatever genealogies the new genealogy offers, they hit home only insofar as they avoid the genetic fallacy and, even then, only in regard to conceptions saliently like the problematic ones - that is, like them in virtue of their problematic features. If even concepts as poisonous as slurs can sometimes undergo transformation such that we can speak of different conceptions, how much more concepts like religion or religious freedom, whose legacies, however checkered, are by no means as univocally poisonous. ${ }^{3 \mathrm{I}}$ We will consider those concepts in some detail below. What is important to note now, however, is that even if the new genealogy is right about intractable bias relative to some conceptions of religious freedom, it has not considered or shown anything about all conceptions, least of all the holist, dialectical conception I sketch later in this article.

While the new genealogy successfully undermines foundationalist pretensions of Neutrality, it wrongly imagines this critique tells against religious liberty generally. Once we reject this elision of Neutrality and fairness, of unjust bias and principled evenhandedness, and once we recognize this critique as pertaining only to certain corrupt forms and conceptions of religious liberty, we clear space for alternate visions.

\section{Power as Unethical}

For the new genealogy, religious liberty is, above all, a site of state power. The revelation that power is and always has been and will be at work in religious liberty is supposed to count against religious liberty. Fundamental to the critique is the assumption that power is itself ethically problematic. State power is exclusively unethical, oppressive, and dominating. As a paradigmatic expression of that power, religious freedom is too. ${ }^{32}$

Religious freedom, the new genealogy claims, is a tool of oppression that bifurcates religion into a private, interior essence beyond state control, and a bodily domain subject to state power (SAQ, 3-4). Beyond subjugating bodies, the very bifurcation epitomizes state power. While claiming "to be neutral ... religious liberty [is] a technology of [the] modern state ... deeply implicated in the

30 This is so even if that conception shares certain features in common with a problematic contemporary or ancestral conception-just so long as the shared features are not the problematic ones. Recall the example of "queer" when proudly used by a gay man to refer to himself and other gay men. That conception shares with some problematic contemporary and ancestral conceptions the feature of picking out the same group of people. It differs, however, in what it enacts and authorizes in its application to that group.

3 I No scholarly work that I know of makes this case concerning conceptions of religion as persuasively or demonstratively as does that of Jeffrey Stout, "Religion Unbound: Ideals and Powers from Cicero to King," 20I7 Gifford Lectures, University of Edinburgh, May I-II, 20I7, https://giffordsedinburgh.com/. Should any doubt that there are profound differences between religion and racial slurs in respect to violence, simply consider the major differences in most contexts between reactions and norms surrounding using the "n-word" as opposed to those surrounding use of religion-differences evidenced even in my elliptical reference or the casual mention or use of religion as opposed to the "r-word" by even its harshest genealogical critics.

32 There is a connection here to the identification of freedom and noninterference: power involves interferences and is thus a tool of unfreedom. In Religious Difference, Mahmood says she rejects power-reductionism in relation to religious freedom; see, for example, 20-2I. Those with exegetical aims would need to reconcile that claim with her remarks in PRF, SAQ, and those in other texts that have been cited in this article. 
regulation of religion" (SAQ, 4). Indeed, "the secular state is necessarily involved in regulating ... religion and often prescribing substantive content while ... claiming to treat ... its citizens equally regardless of their religious commitments" (my emphasis, SAQ, 6). Religious liberty is not only interference and thus unfreedom, nor merely profoundly biased, it is an ideological operation of state power-and, thus, inherently oppressive and dominating. The divisions and controls it effects are "a-if not the-distinguishing feature of modern secular power" (BRF, II). It "essentially allows the state simultaneously to uphold the immunity and sanctity of religious belief even as it regulates the manifestation of these beliefs" (SAQ, 5). It is a "technology of modern governance that ensures the state's sovereign right to regulate all domains of social life," and "privileges the beliefs, values, and practices of the majority religious tradition in any given polity" (SAQ, 5). So, rather than a possible means to protect the disempowered, religious freedom is a means whereby the many can control the few and the state can manipulate and oppress everyone (SAQ, 6). "A contingent power arrangement of the modern West" (BRF, 59), it is "cover for ... suppression" and "central to a politics of local containment ... neo-colonialism and imperialism" (JLR, 360, 362) by which the state would "transform ... difference into sameness" (PRF, I43). The irony and ideology of religious liberty, then, is that it harms those it claims to help, enforces sameness rather than allowing diversity, and maximizes state power instead of restraining it. Moreover, none of this is a "corruption of the right to religious liberty [but is] internal to the conceptual architecture of the right" (PRF, I47), "internal to the concept of religious liberty itself" (SAQ, 4).

Thus, as an "operation of modern secular power [that] generat[es] new forms of religious prejudice and enhanc[es] old ones" (SAQ, 6), religious liberty not only exacerbates the violence and conflict that plague our world, it actually creates such conflict. 33 "Enormously productive and transformative of religious identity, often hardening existing lines of religious difference," religious liberty effects the very divisions and antipathy it is supposed to heal (SAQ, 7). "Creating new forms of communal polarization," 34 it scripts diverse individuals and communities into subjects whose agency and particularity are disappeared by the procrustean religious liberty narrative: "'Religions' begin to perceive themselves as they are portrayed ... as hidebound communities, static bodies of convention. ... Boundaries are settled. Orthodoxy is established. ... You can be this or that, but not both" (PRF, 53). This marginalizes those who do not conform and generates and sustains pitched, often bloody, battles. Ironically, religious liberty actually causes so-called religious violence: "far from being an instrument of neutrality that protects religion or its practitioners, the right to religious liberty also helps create new identities, reifies religious difference, furthers state regulation $\ldots$ and $\ldots$ facilitates the hegemony of powerful geopolitical actors" (SAQ, 7). Unmasking this as religious liberty's "performative and productive capacity" is one of new genealogy's "basic arguments” (SAQ, 7).

Consider this argument: There are complex patterns of oppression and violence directed against some socially or politically weaker party that we are tempted to identify as somehow implicating religion. We imagine that legal intervention prohibiting religious persecution and empowering the persecuted will help. Yet the very categories we are tempted to deploy were birthed in and embody oppression. Their use extends and deepens that oppression and distorts the identities of those we meant to protect-marginalizing them further. Religious liberty only makes things worse and births new problems. Best then to abolish religious liberty and laws prohibiting religious discrimination-and better to dissuade so-called religious minorities from understanding

33 See also PRF, 4-5, 7, I47; JLR, 360; BRF, 48, 49-50, 53, 54; Mahmood, Religious Difference, I 5.

34 Mahmood, Religious Difference, 2. 
themselves in those terms or deploying the tools or rights associated with religious freedom to protect themselves against oppressors or to hold states accountable.

Now, this entire argument could equally well be turned against legal concern with race and protections against racial discrimination. I do not see on what grounds the new genealogy could avoid this entailment: its arguments seem to oblige it to remove race as a protected class or as figuring in law at all. ${ }^{35}$ For race is no less a constructed and contested category than religion. As Jay Carter, Willie Jennings, Cornel West, and others have argued, it was birthed in and extended colonialism, violence, marginalization, and oppression - much more clearly and unambiguously than religion. ${ }^{36}$ Far more obviously, consistently, and unambiguously, race has functioned in law as a tool of oppression and state power, marking out some for privilege, others for subjugation. Arguably, until relatively recently, that has been its primary function. Yet even if we suppose that legal categories of race necessarily involve certain forms of reification, division, and constraint, can we seriously imagine that racial minorities - such as blacks in the United States-would be better off without legal protections against discrimination, oppression, marginalization, exploitation, and violence directed at them in virtue of their race? That the law should not attend to the ways in which patterns of oppression, violence, and discrimination by the state, police, and majoritarian communities and individuals are disproportionately directed against blacks? That a movement like Black Lives Matter would be better empowered to pursue justice and equity without the legal mechanisms such as those that allowed the US Department of Justice to investigate and effect change within the Ferguson Police Department?37

People act for reasons. Among those reasons are matters to do with perceived realities of race, religion, sex, sexuality, ethnicity, and the like. We need not think that every instance of apparent racist or religious violence admits of a simple, mono-causal explanation to recognize that sometimes and perhaps often this perceived difference and the category associated with it are reason enough to make an outsider or minority a target. $3^{8}$ All kinds of factors cause communities and individuals to act hatefully toward those they perceive as different. Medieval Christians targeted Jews for abuse and terror long before "modern religious liberty" came along. Sometimes this was motivated by identification of Jews as guilty of deicide or host desecration. This happened frequently

35 A new genealogy unwilling to banish race from law owes an account of how and why race and race-related protections are saliently different from religion and religion-related protections. See BRF, I 2 I-22.

36 Carter, Race: A Theological Account (Oxford: Oxford University Press, 2008); Jennings, The Christian Imagination: Theology and the Origins of Race (New Haven: Yale University Press, 20Io); West, "Race and Modernity" in The Cornel West Reader (New York: Basic Books, 1999), 55-86. Regarding the complexity and ambiguity of religion, to take a single example, Stout has shown how early modern Dominicans such as las Casas deployed a conception of religion precisely to protect indigenous American peoples and to critique their imperial oppressors. For las Casas, to the extent that Westerners war against, enslave, or otherwise exploit Indians, they violate and demonstrate their own lack of religion. Jeffrey Stout, "Lecture Two: Early Modern Critics of Tyranny and Oppression,” 2017 Gifford Lectures, University of Edinburgh, May 2, 20I7, https://giffordsedinburgh.com/2017/05/03/lecture-two-early-modern-critics-of-tyranny-and-oppression/.

37 Martha Albertson Fineman contends for a version of equal protection that relies less exclusively on "protected classes" but, vitally, aims to extend protections and render them more comprehensive, systemic, and equitable. "Anchoring Equality in the Human Condition," Yale Journal of Law and Feminism 20, no. I (2008), I-24, at 2I. Yet even to achieve such aims, on my view, requires allowing such categories to continue to figure so as, at the very least, to be able to measure or evaluate progress in relation to those whose (perceived and/or assigned) identities render them more vulnerable than others. That is, so much as to judge the merits or success of such proposals requires us to deploy the concepts in question.

38 On the relation between categories and these perceived differences, see, for example, Sally Haslanger, Resisting Reality (Oxford: Oxford University Press, 20I2), especially 22I-47. 
enough that Jewish leaders regularly petitioned the Catholic Church for protection. 39 In other cases, the proximate occasion of persecution was not obviously "religious" - a missing child, say. But Jews were an easy target for blame and attack in such cases in virtue of their manifest otherness and lack of effective legal protection. Precisely their subordinate, disempowered status and religious identity-expressed through their "strange" practices and obvious rejection of Christianity-made them ready targets even in these cases. Likewise, blacks under Jim Crow were sometimes targeted as an explicit act of racial terrorism, with the very intent of terrorizing and further subjugating them, thereby extending white supremacy. Sometimes they were attacked because a white teenager became pregnant and a trumped-up charge of rape followed-but, here too, it was racism and "blackness" that rendered them targets. In both cases, no analysis of what happened or why it happened would be complete that did not take account of race. The same must be said for religion when it comes to medieval Jews amidst Christian Europe. It did not take the nation-state or religious freedom to constitute Jews as religiously other; Christian practice and theology took care of that just fine. Nothing in history or scholarship suggests that such patterns of behavior are unique to Christianity.

Among the reasons individuals and communities have found to marginalize, abuse, and attack one another are religious reasons: targeting some on the basis of one's own or their religious convictions, practices, or identity, or regarding some as outsiders or dangerous to one's religious community. None of this suggests that other factors are not frequently implicated, that religious reasons are necessarily most salient, nor that we can always understand all of the reasons and relations among the factors. Yet sometimes we can understand them relatively well: the agents tell us and their behavior confirms that they are targeting some group because they are idolaters or heretics and so on. Even when we cannot grasp exactly how various reasons are figuring, we can often recognize that religious reasons are implicated, if only because the victims are stigmatized religious minorities and unprotected by law. What laws concerning religious liberty are, at their best, aiming for and doing are basically what laws against racial discrimination are, at their best, aiming for and doing: recognizing a history of oppression and domination and the majority's tendency to ostracize and harm those considered "others," and offering law's protection to clothe the nakedness of their social vulnerability.

This hardly suggests that religious liberty is a panacea. What it suggests is that laws protecting religious freedom are among the best tools we have for preventing the targeting or domination of individuals or communities on the basis of their religious otherness. Laws can indeed encode and extend oppression. That is just what Jim Crow did. That is just what medieval Christian laws concerning Jews did. But that is not the only thing law can do. The US Voting Rights Act sought to secure blacks against domination and to give them a voice in governance. Long before that, the thirteenth amendment to the US Constitution abolished slavery. In both cases, these legislative acts were backed up with the threat-and sometimes the mobilization-of state power. Neither is fully thinkable without the concept of race and its deployment in law. At their best, laws outlawing religious persecution seek to protect and give voice to religious minorities, putting them on equal footing with majoritarian communities. The new genealogy collapses the difference between racist and religiously prejudiced regimes of law and those that, however imperfectly, seek to protect minority communities from oppression. And it would rob such communities of some of the best

39 See, for example, Jeremy Cohen, Living Letters of the Law: Ideas of the Jew in Medieval Christianity (Berkley: University of California Press, I999); David Decosimo, Ethics as a Work of Charity: Thomas Aquinas and Pagan Virtue (Palo Alto: Stanford University Press, 2014), I7-39. 
tools they have for resisting persecution and standing before fellow citizens and their government without fear.

There is no doubt that such legislation can be abused, enforced in biased ways, and harden identities. But there is a great distance between these things and the real goods it seeks and often secures. And there is a far greater distance still between its incidentally doing such things and the legislation of oppression, racism, and discrimination that states sometimes pursue. The new genealogy does not adequately acknowledge these differences, collapsing all pursuit of religious liberty into one oppressive, ideological operation of state power.

It would be absurd to suggest that mid-twentieth-century US laws enacted to protect blacks, laws demanded by blacks and their allies, were the cause of the lines of racial difference and discrimination they sought to address. Those differences and that discrimination long preceded those laws, even as racist laws helped make them necessary in the first place. Citing racist backlash against civil rights laws or unintended bad effects as reason not to pursue them was the very argument "white moderates" gave as to why blacks should stop protesting and avoid "creating tension." While many of us would welcome a post-racist, post-religious bigotry world, that is not the world that actually exists, least of all for the most vulnerable. Communities continue to act against each other for reasons related to religious and racial identities. So long as they do, those who would argue for abandoning race and religion as legal categories have a heavy burden to bear. They will need to show that the harms done to minority communities by legislation they support and help craft, laws aimed at protecting them and equipping them to hold governments and fellow citizens accountable for wrongs done on the basis of racial and religious identity, are greater than the benefits such legislation secures. The new genealogy of religious freedom has not begun to make that case.

\section{THREE TYPES OF GENEALOGY}

As we have begun to see, entangled with and animating the new genealogy of religious freedom's entire critique is its character as genealogy. In regard to freedom, neutrality, and especially power and in regard to these three collectively, the new genealogy of religious freedom proceeds by ostensibly unmasking religious freedom's true and profoundly problematic nature. It purports to show religious freedom as not only inherently contradictory, ideological, and biased, but rooted in and expressive of the very evils it claims to oppose. This is genealogy par excellence. And yet, the new genealogy of religious freedom's relation to genealogy remains ambiguous.

For one thing, the new genealogy of religious freedom vehemently rejects oppression, even as it regards power as ubiquitous and identifies power with oppression. But this raises questions about its own status: how the new genealogy of religious freedom itself avoids the will to mastery and entanglement in oppression that it supposes nothing else, least of all religious freedom, can escape. Further, universalist, essentialist claims about religious freedom are the new genealogy of religious freedom's hallmark, yet genealogy trades in specificity, particularity, and multiplicity, and it undermines notions that principles and concepts have essences and rejects appeals to or attacks on the "very idea" of something. Where genealogy uncovers hidden histories that may (or may not) matter for some extant conception, the new genealogy of religious freedom slides into genetic fallacies, forgetting that the history of one conception of some ideal may have little to do with some other and that it is an open question what some history means for some extant conception. All this raises questions concerning the sort of genealogy that the new genealogy of religious freedom pursues and how it comports with its critical agenda. 
To answer such questions, we can distinguish among three types of genealogy: historical genealogy, Nietzschean genealogy, and new genealogy. $4^{\circ} \mathrm{New}$ genealogy, of which the new genealogy of religious freedom is but one expression, is caught between the coherent options of historical and Nietzschean genealogy, exhibiting features of both in ways that are finally incompatible.

Historical genealogy names the commitment to be maximally honest about all the factors that have gone into making our values, practices, institutions, and arrangements what they are, along with their consequences and the interests they express. Rather than resting content with received stories about the origin and character of the concepts, structures, and ideals that animate and order our lives, genealogy strives to unmask what really happened, to explain how these concepts and practices came to be, what they have variously meant, and how they have functioned. Inherent in historical genealogy is a willingness to revise what has hitherto been taken for granted or even treasured - not only our stories about our values and practices but those values and practices themselves. In this regard, there's an inherently risky and frequently subversive dimension to historical genealogy. Truthfulness may have a price. Unsavory, contingent, and even violent forces may have birthed or defined some value or practice, its use or ends, ascent or decline, unquestionability or unthinkability. Yet because historical genealogy's commitment is to honesty, one must be no less attentive to other forces than the unsavory. Historical genealogy demands a tremendous degree of exacting, detailed, and wide-ranging historical work. Notwithstanding its frequently debunking swerve, it admits of a variety of ethical and critical uses. What is essential is that accountability to evidence and a commitment to careful interpretation are at the fore-whatever the normative implication or lack thereof. It is one thing what historical genealogy shows; another thing-and beyond historical genealogy's purview - to what use its various deliverances are put.

What links Nietzschean genealogy to historical genealogy is a commitment to questioning received stories and unmasking alternative accounts, while at least purporting to be more honest. What distinguishes Nietzschean genealogy is its explicitly normative aims: it discredits and de-values esteemed principles, practices, institutions, or arrangements by suggesting they are products of unsavory processes or aims-ideally, unsavory in view of the principle in question. Such genealogy causes standard stories about some principle and its origins to seem suspect, untruthful, or self-deceived, and ongoing commitment to that principle to be regarded as extending unsavory dimensions of its alleged past. Thus, On the Genealogy of Morals contends that Christian "love" and "meekness" arose from and express hate and ressentiment. Unlike historical genealogy, where honesty means careful historical sensitivity to every important dynamic at play, for Nietzschean genealogy there are no other forces to be found than will to mastery, pursuit of the upper hand. Here, power pervades all and goes all the way down. The only question is who holds it. The values that animate our lives, especially those that seem sacred, derive from and are tools of agonistic battle. Nietzschean genealogy purports to unmask this. It matters not whether some account is accurate; only that it captures the imagination. And its success in eliciting dis-valuing swings free from its truth. This dis-valuing end inheres in the method, whatever the practitioner's intentions: it cannot but subvert prized values to see them as rooted in and expressing the very forces they purport to oppose.

40 In labeling this "Nietzschean" genealogy and referring to Nietzsche, I am not making claims about how Nietzsche's own complex vision of genealogy is best understood but identifying a type associated with an influential way of reading and inheriting Nietzsche. These are ideal types and are neither comprehensive nor exhaustive. For an alternative mapping, see Bernard Williams, Truth and Truthfulness: An Essay in Genealogy (Princeton: Princeton University Press, 2010), especially $20-38$. 
The new genealogy occupies an uninhabitable terrain between the conceptually coherent alternatives of historical and Nietzschean genealogy.4r While ostensibly marshaling evidence in the manner of historical genealogy, its claims - comprehensive, universalist, and essentializing - outstrip that evidence. Instead, in substance and function and relative to the conclusions drawn, its evidence is more like Nietzsche's philological data in On the Genealogy of Morals. More profoundly, it shares with Nietzschean genealogy the debunking aim. It would show treasured ideals like "religious freedom" or "human rights" to be impossible fantasies, tools of oppression, ideological weapons. Having declared religious freedom, essentially, a colonialist tool, technique of state discipline, and cause and expression of subjugation, intolerance, and violence, the new genealogy of religious freedom's rejection of religious freedom could hardly be clearer. Like Nietzschean genealogy, it is normative through and through. In this, these two species of genealogy are united.

Yet where Nietzschean genealogy could hardly be more explicit, wholehearted, or unequivocal about its aims, new genealogy often seems uncertain, uncomfortable, or in self-denial concerning its own robustly normative character. While launching its attack on religious freedom, human rights, or the like and describing itself as pursuing genealogy, it also presents itself as not interested in advocacy, evaluation, judgment, or any normative venture, avowing instead commitment to scholarly analysis. $4^{2}$

Its "intent is neither to promote nor reject the right to religious liberty" (PRF, I43). It "does not take a position for or against religious freedom" (PRF, 2) but merely want us to consider "that, before either championing religious freedom of rejecting it, we need to understand the complex social and legal lives of this concept." It is not interested in a "political manifesto" (PRF, 2), but a "reorient[ation of] thinking about ... religious freedom" (JLR, 358) to help us "learn ... from examining this often messy story" (PRF, 2). Lest we mistake this self-proclaimed non-normative agenda for indifference to suffering, we should know that it is simply concerned "whether advocacy for religious freedom ... is the best way to achieve peaceful coexistence" (JLR, 358). The new genealogy of religious freedom "share[s] a concern ... about the persistence of what is often misnamed religious persecution" ( $\mathrm{PRF}, 3$ ), but it simply doubts such violence is usefully described as religious - and worries that doing so may make matters worse (PRF, 3 ). Above all, it counsels - and seeks to exemplify - "epistemological and normative humility" (JLR, 36I). The "common thread running through" the work "is a reticence to prescribe solutions and a sense of humility in the face of challenges posed by deep social and normative diversity" (JLR, 36I). The common thread is, in a word, "modesty" (JLR, 36I). We should "step back from the seductively over-simplified" (PRF, 5), "utopian space" (PRF, I 5 ) of "a single-minded focus on religious freedom" (JLR, 360), one that imagines religious freedom as "the key to emancipating individuals and communities from violence, poverty, and oppression" (emphasis in original, PRF, I); "the gospel ... [that] lead[s] comprehensively to democracy, greater civil and political liberty, and prosperity" (PRF, I); or "the answer to the many challenges of ... social and political life" (JLR, 36I).

Yet all of this sits right alongside the rather intense criticisms we have seen, which claim that religious freedom is inevitably biased (SAQ, 4); "intentionally duplicitous" (PRF, 9); "pretend" (PRF, 8); "an operation of modern secular power [that] generat[es] new forms of religious prejudice

4I While new genealogy is a broader phenomenon, I focus here on the new genealogy of religious freedom as representative.

42 Thus, one volume seeks "to understand the contested historical genealogy of the concept of religious liberty" which involves showing how "this seemingly obvious and neutral right has yielded mutually contradictory and often discriminatory results" (my emphasis, PRF, 2; for other examples, see PRF, 5, 7, 240-52). 
and enhance[es] old ones" (SAQ, 6); and a statist tool for "mind control" (PRF, I4 and 55), "minoritization" (JLR, 359), neocolonialism, and imperialism (JLR, 362).

This apparent double-mindedness is further manifested by the frequent appearance of implicature in the new genealogy. Implicature is a speech act in which some claim, without being explicitly stated or strictly entailed, is nonetheless issued. ${ }^{43}$ Implicature allows for criticism with plausible deniability, even deniability to oneself. Perhaps even unbeknownst to oneself one conveys by implicature what one does not fully recognize oneself as committed to. One key way the technique figures in the new genealogy is in its use of long lists of questions. Ostensibly these questions simply chart the terrain to be explored. But consider one such list, from Politics of Religious Freedom's programmatic introduction, and notice what the questions convey by implicature:

- Do [the accounts in this volume] mean that religious freedom is always a governance project, a flattening of "factual" complexity to suit particular regimes of domination? Are religious identities, practices, and communities unusually affected by these flattening processes-more so than other social realties - such that the legalization of religion remains distinctively problematic?

- How are religious self-understandings altered through processes associated with the liberal management of religious diversity?

- To what extent are the schematizing, routinizing tendencies intrinsic to law generated or amplified in modernity?

- Is there something distinctive about religion under modern legal technologies in this regard?

- If legality always requires translation or abstraction from complex social realities, what is actually being protected under the rubric of religious freedom?

- If law's role is to transform life-to misrecognize and transmute reality into rules and regularities legible to law-why do we pretend that law can recognize and protect religious lives and complexities? (my emphasis) (PRF, 8; bullets added for clarity)

While these are presented as questions, it is difficult to miss the implied answers or what the questions themselves convey. On the immediately preceding page readers have just been told that "to continue to use the word [religion] in law is to invite discrimination" (PRF, 7). Legal action to protect religion is not only unjustifiable but makes matters worse, perpetrating discrimination. And in the list here, the climactic question claims that to think law can recognize and protect religious lives and complexities is "pretending." Religious freedom is a fantasy. The implication is that some religious freedom advocates know it is a fantasy. The next sentence makes this explicit: "We have come to see [pursuit and talk of religious freedom] as a deeply ambiguous, even at times intentionally duplicitous, legal standard" (my emphasis, PRF, 8-9).44

The recurring presence of a rhetoric of prudence and caution alongside clear, strident critique, the appearance of implicature, and the absence of positive proposals, suggest that the new genealogy is less than comfortable with or fully attuned to its own normative status. ${ }^{45}$ But if religious

43 On implicature see H. P. Grice, "Logic and Conversation," in Studies in the Way of Words (Cambridge, MA: Harvard University Press, I99I), 22-40.

44 Another example: "How does a particular definition of religion imply a particular politics? Can we get beyond these entanglements?" This first question presupposes that any definition of religion does imply a particular politics. The subsequent sentence says we cannot "get beyond these entanglements": "This section ... explore[s] what might be meant by religion for religious freedom and the ways in which any such meaning is necessarily inflected by shifting connections among religion, law, politics, and freedom" (my emphasis, PRF, I3).

While our aim is not synthetic exegesis of entire texts, note that BRF does advance constructive proposals. 
freedom really is the vicious tool of oppression that new genealogy claims does not it-along with Orientialism, racism, sexism, and any number of vicious ideologies-deserve forceful, wholehearted condemnation?

\section{BEYOND NEW GENEALOGY}

Consider again historical and Nietzschean genealogy. Historical genealogy can be put to any number of uses - savory or unsavory, subversive or supportive, liberative or oppressive. It is conceptually stable, self-referentially coherent. Nietzschean genealogy, in contrast, is haunted by power-reductionism, the assumption that agonism and will to mastery pervade all. This basic commitment raises fundamental doubts concerning its capacity to account for itself. ${ }^{6}$ Nietzschean genealogy can even seem to self-destruct. For if everything is reducible to power struggles, what of genealogy? Either genealogy is itself another attempt at mastery or it is not. If it is not, then power relations do not exhaust human affairs after all. Instead, other dynamics-recognition, friendship, respect, mutuality, love-are present and need to be recognized. But then, Nietzschean genealogy is false. And it fails to account for these realities.

The alternative is to concede that genealogy itself is but another attempt at mastery. On one reading, that is just what Nietzsche does, only he does not concede-he embraces. He embraces the notion that everything, genealogy included, is struggle for mastery. He thereby secures a kind of consistency for his genealogy. But this comes at a high price-at least for domination's opponents. It requires embracing mastery, abandoning critique of oppression.

Most simply, new genealogy shares the power-reductionism of Nietzschean genealogy, but not its enthusiasm for mastery. When it comes to religious freedom, nation states, human rights, or whatever, it can find only ideology, oppression, and domination, but it wants to condemn these things. Yet new genealogy is aware on some level that this puts its own status as critique into question: If the will to mastery pervades all, what of its own discourse? Where Nietzschean genealogy is robust, new genealogy is halfhearted. It regards pursuit of mastery as vicious but fears such pursuit is inescapable. It unmasks oppression because it regards oppression unjust, but remains unsure how any alternate ethical vision can avoid the same unmasking. So, new genealogy finds itself equivocating about its own status and commitments, wavering between claims to measured caution and intense critique, prudential analysis and self-described genealogy. It denies critical aims even as it pursues them-manifestly and by implicature. Haunted by the status of anything normative it might claim, it can neither fully acknowledge its opposition to religious freedom nor venture an alternative. Yet it continues to unmask. It is neither willing to embrace power-reductionism wholeheartedly, nor able to let it go. The new genealogy seems to want what it cannot have: to reject domination but to find nothing anywhere but the will to it.

Nietzsche would likely regard the new genealogy as genealogy without the courage of its convictions, genealogy trapped in the dank tomb of concern for good and evil. But why should we count the embrace of domination as courage? Instead, a commitment to rejecting dominationwhich I believe is what finally animates new genealogy-requires leaving both Nietzschean and

46 Leaving aside whether his interpretation of Nietzsche is accurate, on the instability of Nietzschean genealogy, see, for example, Alasdair MacIntyre, Three Rival Versions of Moral Enquiry: Encyclopaedia, Genealogy, and Tradition (Notre Dame: University of Notre Dame Press, 1990): especially 32-57; see also Thomas A. Lewis, Why Philosophy Matters for the Study of Religion-and Vice Versa (Oxford: Oxford University Press, 2015), I44-60. 
new genealogy behind. It requires acknowledging that agonism and struggle for mastery, however important their roles, do not adequately account for human practices, institutions, and principlesreligious freedom included. Pursuit of justice and mutuality can animate and be imperfectly realized by even some versions of religious freedom.

As it stands, new genealogy remains caught between Nietzschean genealogy that confesses its status as will to mastery and historical genealogy that rescinds from essentialist pronouncements about the very idea of religious freedom and is no less sensitive to forces of justice and mutuality than to struggle for mastery. So long as it would reject domination, the way forward leads beyond itself and Nietzschean genealogy alike. And while any resistance to domination will find historical genealogy indispensable, it cannot stop there. If it would be put to use resisting domination, historical genealogy itself needs the guidance and motive power of an ethical vision, elaboration, and defense of inclusive non-domination. And that is more than any genealogy alone can supply. It requires constructive philosophical labor.

Beyond these ethical matters, new genealogy is incapable of the work that the new genealogy of religious freedom asks of it in yet another way. Only if there were such a thing as the very idea of religious freedom, some singular, fundamentally unchanging essence underlying countless manifestations and possibilities, could it count against religious freedom generally or every idea or practice of religious freedom that some past or present versions are problematic. But the very idea of religious freedom is just what genealogy denies. Two of its most important lessons are that concepts do not have essences and that, thanks to its history or our choices, a given concept may admit of a whole host of diverse, competing conceptions. 47

In this respect, the new genealogy of religious freedom is insufficiently genealogical. The new genealogy of religious freedom neglects both historical genealogy's nonessentialist vision of concepts and the sensitivity to particularity and diversity that historical genealogies help us trace. One of the signal virtues of historical genealogy is precisely to map this diversity, showing how a given ideal can diverge into diverse-even incompatible-conceptions. Tracing just one pathway of one conception takes a tremendous degree of very careful historical work - at the conclusion of which we can still ask of some conceptual heir whether or not it is entangled in whatever is shown of its past. So far new genealogy has neither pursued this kind of work nor avoided genetic fallacies.

The new genealogy of religious freedom is right to reject any notion of religion or religious liberty as domains untouched by power or politics. It successfully shows how the idea that "religious freedom stands outside of struggles for power, serving as 'a polestar that can guide political action without being contaminated by it'" is not only false but dangerous (PRF, IOI). It is surely correct in holding that power plays a profoundly important role in religious liberty. These are extremely important and necessary points. But the new genealogy of religious freedom is mistaken in how it understands this and what it takes this to mean. First, it tends to see the agonistic struggle for mastery as exhausting the forces at work in religious liberty. Pursuit of equity or mutual recognition does not figure in religious liberty or state action at all. It is only power, all the way down. Second, it implicitly regards power and its pursuit as necessarily problematic and unethical: the struggle for power is always the struggle to dominate, and power's exercise always exemplifies domination. These assumptions animate its entire critique. I reject them both.

The new genealogy is mistaken to imply that power exhausts what is important about human affairs, including those we regard as political, religious, or both. We have just seen how that

47 BRF's repeated claim that "religion is too unstable a category" to figure in law (BRF, 6, I3, I 2I; cf. 67) seems caught midway between acknowledgment and neglect of the former point, as though religion has an unstable essence, as though it is essentially unstable. 
view self-destructs. It is also mistaken to suppose that the operation of power necessarily taints or corrupts some domain or value. And it is mistaken in equating power with oppression, the struggle for power with the will to mastery. We will see why shortly. But recall first that in its clearest moments the new genealogy of religious freedom regards its unmasking of power as critique. It rejects what it sees, regarding it as oppressive ideology. Yet this rejection itself embodies and presupposes an ethics. What it rejects is, most simply, domination. But to simultaneously insist on the ubiquity of power operations and to reject domination is implicitly to presuppose that domination is not identical to power or power asymmetries. Otherwise one's rejection and critique is reducible to yet another attempt to master or dominate. Instead, domination must name a species of unjust power relations. The rejection of and struggle against domination is a struggle for power and for re-shaping power relations. This struggle is not identical to trying to turn the tables or gain the upper hand. The new genealogy of religious freedom's own critique, then, necessarily presupposes the non-identity of domination and power, a distinction between domination and powerasymmetries. Its very opposition to domination should thus impel the new genealogy of religious freedom away from new or Nietzschean genealogy and toward historical genealogy and dialectical, democratic republicanism. The rest of this article begins to elucidate what this dialectical, democratic republicanism amounts to. It does so by re-visioning power, freedom, and neutrality.

\section{DIALECTICAL, DEMOCRATIC RELIGIOUS FREEDOM: REIMAGINING POWER, FREEDOM, AND NEUTRALITY}

\section{Power and Freedom as Non-Domination}

In this section, I sketch an alternate, democratic "republican" vision of power and freedom, on which the two are intertwined. Here, unfreedom is subjection to a certain power asymmetry. But not every power asymmetry is ethically problematic or freedom-destructive. Indeed, some power asymmetries are necessary for and help realize social goods. On this view, freedom is constituted by certain sorts of relationships. It concerns not atomistic individuals and noninterference but persons as always, already embedded in right relationships and their obligations.

Recall the claim: "To be free ... is ... to have the ability to choose for oneself in all areas of life, without restraint" (IRF, I 56). Call this vision of freedom as noninterference-shared by foundationalism and the new genealogy - "liberal freedom." The new genealogy assumes liberal freedom represents an animating ideal of the state and secularity. Religious freedom is and must be paradigmatic liberal freedom. This fuels the new genealogy's insistence that religious freedom is both impossible, thanks to the way defining religion constitutes interference, and inherently biased, thanks to liberal freedom's hyper-individualism. Republicanism, in contrast, rejects liberal freedom's individualism and public/private, secular/religious dichotomies. It requires diverse, robust communities and regards religious interchange, activism, and debate as helping constitute freedom. Far from being particularly modern or secular, its roots run from Cicero through the Italian city-states, the seventeenth-century Dutch republic, English commonwealthmen, American founders, abolitionists, suffragists, the settlement house and civil rights movements up to contemporary broad-based community organizing. ${ }^{4} 8$

48 See, for example, Philipp Pettit, Republicanism: A Theory of Freedom and Government (Oxford: Oxford University Press, I999), I7-50; Quentin Skinner, Liberty before Liberalism (New York: Cambridge University 
Republican liberty is security against domination, freedom from mastery. The master/slave relation is the paradigm of domination. While the relational paradigm itself and questions of resemblance thereto take priority in discerning whether some arrangement constitutes domination, we can also venture ad hoc formulations and principles of assessment. Thus, we can say that a person or community is dominated when someone is in a position to exercise arbitrary power over that person or community. If power is "the capacity that an individual, group, or institution has to produce effects that people would have reason to care about," what it means for power to be arbitrary is complex and contestable.49 Still, we can identify paradigm instances and offer various ad hoc principles. So, power is arbitrary when it fails to meet a reciprocity test (for example, dominator would not exchange places with dominated); it is not governed by norms constitutive of relations of mutual respect; the power differential lacks a rational basis, unlike that between teacher/student or parent/child; the dominator is not accountable to the dominated; the roles (for example, tyrant, serf, detainee) constituting the relation are such that no one would willingly occupy them; and so on. $5^{\circ}$

Power differentials alone do not constitute domination. Domination involves arbitrary power. Other things being equal, parents, bosses, and teachers do not count as dominating employees, students, and children in virtue of their superior power. Rather, domination pertains to power differentials that are arbitrary in ways like those detailed above.

A slave lives at the master's mercy, in perpetual terror of what the master might do. As eighteenth-century republican Richard Price explains, those "under the power of masters cannot be denominated free, however equitably and kindly they may be treated," for even under a "benevolent" master, a slave suffers the crippling knowledge of her total vulnerability..$^{5 \mathrm{~T}}$ They depend on nothing more stable than a master's will for their security - and that will may change from benevolence to indifference or hostility at any time. Whether the master actually beats, chains, or otherwise interferes, he can and this constitutes a deep form of unfreedom. This is domination. On a liberal view, in contrast, so long as the master does not actually interfere, the slave is free.

Where the new genealogy blurs or elides the distinction between power asymmetry and oppression, republicans agree that no human community is bereft of power asymmetries but insist on distinguishing between just and unjust species of power, violence, and politics. To begin to grasp the point, consider the following relations: slavelmaster, athletelcoach, adviseeladvisor, young child/ loving mother, parishioner/priest, UK citizen/MP, North Korean citizen/president, citizen/state. If we fail to distinguish between just and unjust forms of power, we cannot ethically distinguish among these relations. Each will count as ethically similar, alike in respect of power and thus

Press, 20I2); Stout, "Religion Unbound.” These histories render implausible the new genealogy of religious freedom's tendency to equate modernity with liberalism and noninterference.

49 Jeffrey Stout, Blessed Are the Organized (Princeton: Princeton University Press, 20I0), 55. Note well, these effects may include states of affairs, social arrangements, relational (im)possibilities, and so on. Among the effects people might have great reason to care about is precisely that effect which is maintenance of the status quo or prevention of change, whether generally or in the face of efforts at transformation. So, the most powerful in some group may be those with the greatest capacity to keep things as they are: themselves in power; others under their sway. I thank Caroline Kory for spurring this clarification through questions on this point.

50 I offer similar discussions of domination in David Decosimo, "An Umma of Accountability: Al-Ghazālī against Domination," Soundings: An Interdisciplinary Journal 98, no. 3 (2015): 260-88; and David Decosimo "Killing and the Wrongness of Torture," Journal of the Society of Christian Ethics 36, no. I (2016): I8 I-98.

5 I Richard Price, Political Writings, ed. D. O. Thomas (Cambridge: Cambridge University Press, I99I), 77-78, quoted in Pettit, Republicanism, 64. 
oppression. Yet why think the young child/loving mother or teacher/student relation is saliently like the master/slave relation-or that either is like the citizen/state relation?

Instead, we can distinguish at least three types of ethically distinct power relations and roles: just (such as faithful daughter/loving mother), unjust (such as master/slave, subject/tyrant), and indifferent, those too vague to morally evaluate without further detail and contextualization (such as citizen/state, employeelemployer). ${ }^{22} \mathrm{New}$ genealogy effectively reduces all to the second category. Yet who really supposes these relations are saliently alike? That the power by which the child is sent to timeout for hitting is ethically like that by which the slave is chained for sass? That the power by which the justly convicted murderer is imprisoned is ethically like that by which a Falun Gong adherent is jailed in China? Moreover, who would claim that efforts to bring it about that someone is secure against such abuse and empowered to compel the powerful to heed their interests, are saliently like the attempt to get the upper hand or seek mastery for oneself? That these two kinds of power-seeking are ethically alike?

Power and its pursuit can be just or unjust, good or problematic. That states tend to concentrate and conceal power is not sufficient for us to know whether some state is dominating - any more than knowing that someone is an employee, citizen, borrower, athlete, advisee, apprentice, or student suffices for us to know whether she is dominated. Likewise, that some community seeks power does not suffice for us to know whether they seek domination or security against it. When it comes to judging the state or such relations, power asymmetries are both intrinsic to them and insufficient for us to pronounce on their justice. Power and its pursuit are ingredients in domination and nondomination alike.

For the new genealogy and foundationalism, law as such necessarily violates freedom, for law is nothing if not interfering. On this view, the compromise of freedom that law constitutes is tolerated because it prevents still more or worse interference. So, law compromises my freedom to steal to preserve everyone's freedom to enjoy her property. For republicans, in contrast, just law does not compromise freedom at all. So long as some law is just-so long as it is nonarbitrary, as a law against theft is - there is no violation of freedom, for there is no domination. On this view, just laws do not compromise freedom; they help constitute it. There is a vital point here. It concerns the difference between republican and liberal or foundationalist attitudes toward families, religious communities, and the like. These are high interference relations-binding us in webs of obligation, prescribing limits, demanding sacrifice. For liberals they are thus relations of unfreedom. In such a regime, they are, at best, tolerated. The new genealogy rightly unveils liberalism's individualist, antireligious bias. But for republicans these high-interference relations need not be relations of unfreedom at all, for they need not be dominating. ${ }^{53}$ Such relations are not tolerated but celebrated:

52 To be sure, parent/child relations can certainly be or become dominating, even when parents call themselves "loving." My point is that as conceived just here, loving mother is only appropriately applied to those who are not dominating. So, just as knowing that someone is master suffices to know they dominate, as conceived here knowing someone is loving mother suffices to know she does not dominate her children. I leave aside how we might want to classify the parent/child relation generally. Note, too, that there are actually two kinds of occupants of groups one and two: (a) roles/relations that by the very terms are good (king in the classical sense, loving mother) or bad (master) and (b) roles/relations that, in the abstract, belong to group three (such as worker/boss) but come to occupy either group one or two depending on how we further categorize them based on the relevant context and details.

53 Again, they certainly can become dominating - to the extent that power asymmetries or their exercise become arbitrary-such as the parent who abuses a child, the priest or imam who will not suffer any correction or accountability. 
they foster a society that prizes liberty and they realize the good of mutuality. ${ }^{54}$ Republicans seek the flourishing of such relations, for by enjoying good relations in families, religious communities, and the like, citizens not only learn habits of identifying and resisting dominative relations, they actually manifest the social good of freedom. ${ }^{55}$

Non-domination is a common good: enjoyment by one requires enjoyment by many. Imagine a society where women suffer the arbitrary power of men. Now imagine a well-positioned woman whose husband happens not to arbitrarily interfere with her, though he could. To liberals, she is free. ${ }^{6}$ She may help battered wives and advocate laws limiting male interference-but she does so as an individual helping other individuals, individuals who, unlike her, are unfree. ${ }^{57}$ For republicans, in contrast, she is herself unfree, for the community of women is dominated. Concern with her own freedom is concern for the community and vice-versa: "There is no way of removing the domination without altering the conditions under which women generally relate to men." ${ }_{5} 8$

So things go for any other identity, not least religious identities. Ideally, one moves outward in concentric circles of communal identity: parishioners $\rightarrow$ Methodists $\rightarrow$ Christians $\rightarrow$ religionists, for instance. ${ }^{59}$ Republican liberty is an ongoing communal task secured not only by laws but by dispositions to recognize other individuals and communities as similarly deserving of recognition and security against domination. In its democratic form, which we have implicitly had in view, republicanism is committed to ever greater degrees of inclusivity when it comes to who gets to enjoy the benefit of liberty: not merely straight white men, for instance, but strictly all adults in some community no matter their sex, class, education, race, sexual orientation, immigration status - or even their religion.

\section{Beyond Essentialism, Dichotomies, and the Very Idea of Religious Freedom}

When the new genealogy claims that "to be religious is not to be free" (IRF, I 56 ) or "What religion is not is freedom" or "the very idea of freedom of religion is paradoxical; it is the freedom to be unfree" (PRF, 298), we confront the inadequacy of its noninterference vision. It neither captures the way many believers understand freedom nor why they might pursue it. ${ }^{60}$ Ironically, in so conceiving of freedom, the new genealogy actually deepens and reifies a religion/secular dichotomy and essentializes each: religion is unfreedom; the secular is freedom. Religion opposes freedom; states celebrate it (though, so much the worse for them). One must choose: religious practices or political participation, communal identity or civic standing. Freedom can only be secular ideology, wholly alien to religious self-understandings and communities.

54 See Pettit, Republicanism, 32.

55 This and the following paragraph build on Pettit, $5 \mathrm{I}-79$.

56 The example is from Pettit, I23.

57 Republicans note that even here, she will find herself treading lightly, lest she jeopardize the noninterference she happens to enjoy.

58 Pettit, 123.

59 There is no guarantee things will go this way, but they can and should. These communities are communities of "vulnerability classes": what links them are shared markers of vulnerability. Stout, Blessed Are the Organized; Mark Warren, Dry Bones Rattling: Community Building to Revitalize American Democracy (Princeton: Princeton University Press, 200I); and Luke Bretherton, Resurrecting Democracy: Faith, Citizenship, and the Politics of a Common Life (New York: Cambridge University Press, 201 5), show this is no mere abstraction, documenting the work of broad-based community organizing and interreligious communal cooperation in resisting domination.

60 Many Muslims and Christians, for example, operate with multiple conceptions of freedom. See, for example, Decosimo, "An Umma of Accountability." 
Regarding freedom as non-domination dissolves this story, this essentialism, and these dichotomies. It allows for continuity between religious visions and politically pluralist ones and for imagining that religious freedom might echo some value within a given tradition. The new genealogy forecloses that possibility altogether: the very idea of freedom-modern, liberal, and secularand of religion are essentially opposed.

\section{From God's-Eye Neutrality to Principled Evenhandedness}

As the new genealogy has it, liberal states purport to be neutral and agnostic in regard to religion and religious truth. Yet the very idea of religious freedom requires the state to make controversial judgments concerning what religion even is. Thus, the liberal state fails to be neutral; it is "a distinctive kind of theological state" (PRF, 333). Moreover, we here behold its totalizing, ideological essence.

This story depends on the foundationalist identification of Neutrality with neutrality, the premise that neutrality requires not only noninterference but governance according to "God's-eyeview" principles or unassailable deliverances of Reason, natural law, the "original position," and the like. The new genealogy accepts this foundationalist conception of neutrality - and debunks accordingly. But why accept that conception?

The neutrality worth caring about and wanting in governance is a species of justice: a commitment to giving each person and community its due, attending both to desert or what each is owed, and equity or treatment of like cases in like ways. Neutrality names especially a commitment to preventing biases, prejudice, or extraneous interests from distorting this work. A neutrality worth prizing is one that pursues principled, sensitive, humble, evenhandedness, coupled with publicity, openness to rebuke, and procedures for self-correction, contestation, and accountability. Reciprocity principles like the golden rule, mechanisms of accountability, and, once deracinated from totalizing ambitions and dubious questing for foundations, even devices like veils of ignorance and reflective equilibriums can help in pursuing neutrality without foundations. For instance, we imagine being at the mercy of the powerful so that they could do with us as they please. And we imagine, in contrast, what it would be like if they were constrained to listen to us and accountable to us. We prefer the latter. If we would not want to be under unconstrained power, can we, in fairness, seek it ourselves?

Yet, because this vision is dialectical, it is not appropriate to permanently enshrine some necessary and sufficient criteria or formalized principles derived from such tests and simply apply them to each novel case. Foundationalists seek the perfect universal principles so that particular cases can get processed through them. ${ }^{6 \mathrm{I}}$ The new genealogy unmasks the contingency and historicity of principles and cases alike. A dialectical view stresses that such contingency and historicity does not mean our efforts are bound to be un-principled, arbitrary. It further adds that each application of a principle changes that principle.

Think of principles enshrined at the founding of the United States, principles many saw as compatible with slavery and patriarchy. If meaning is a matter of use-the claim "all men are created equal" at that time meant something other than we now take it to mean. ${ }^{62}$ As slaves are freed and women enfranchised-it is not that a once-set principle has been applied to new cases while itself

6I I am indebted to Jeffrey Stout, Democracy and Tradition (Princeton: Princeton University Press, 2005), 77-85.

62 For the purposes of this point, it is irrelevant that some understood that claim actually to mean - "all menincluding black men"-and regarded slavery as in contradiction or tension with the claim (even as some of these nonetheless supported or tolerated slavery's ongoing existence). 
remaining static. Rather, those and other new applications of principles are, simultaneously, transformations of the principle. For the principles' meaning is their use: what they are applied to and the consequences that follow. Legal precedents offer a helpful analogy: the new application of some precedent-in that very application-affects that precedent's meaning, both now and for future cases. And the meaning of the precedent qua precedent is the history of its application to date.

The dialectical departure from foundationalism is not just a matter of a different view of the origin and status of principles but of their role and of the relation between them and particular cases. ${ }^{63}$ When we undertake politics in view of such considerations we can pursue justice and evenhandedness, no matter that these pursuits are ad hoc, contestable, open to doubt, and so on. This pursuit is distinct from seeking mastery or abandoning principles. Let those who doubt that there is a real difference here-who claim rights or principles are only tools for state domination-agree to live under a regime without them.

\section{Religious Freedom and Neutrality Worth Having}

What is required for neutrality-as-evenhandedness? We can easily imagine countless things incompatible with it: outright persecution; treating religionists in capricious, discriminatory ways; conceiving religion in a way that (deliberately or not) systematically privileges the majority, renders it privatized, or construes it in Christian terms; and the like. Positively, evenhandedness would require: special sensitivity to the vulnerable, disempowered status of minority religionists; conceptions of religion that err on the side of including self-identified believers of minority communities and heavily weigh their conceptions of what constitutes adherence to their tradition; care in conceiving of religion so as not implicitly to privilege the understanding favored by or best fitting a religious majority; recognition of judicial tendencies to overestimate knowledge of religious traditions; and so on. In the US and European contexts, this would involve attending especially to features of religion that may not figure in dominant forms of Christianity. Thus, a case like Lukumi Babalu Aye, wherein a contested ordinance forbidding animal sacrifice was generally applicable but Santeria practitioners nonetheless prevailed, would exhibit the neutrality I have in mind. ${ }^{64}$

Now, suppose such a decision does entangle the court in considering the relative importance of some practice to some religion and in weighing that against governmental interests. Suppose, as the new genealogy contends, that the state judges what constitutes religion and even the relative importance of some practice for some religion. The knowledge by which a court makes such judgments need not be arbitrary, biased, or ideological. It should derive from expert and believer testimony, including parties to the case. Such testimony constitutes some of the facts of the case-as it constitutes some of the facts of the course when I teach students what is central to some variety of Islam, what is less so, where debates lie, and so on. If the importance of some practice is disputed, the fact of the dispute should be taken into consideration, along with the difference made by the various contexts in play. None of this seems to violate norms of neutrality or justice. It seems their presupposition. Call all this attention, weighing, and consideration, "talking theology." ${ }_{55}$ How does it serve the cause of justice, fairness, or evenhandedness not to "talk theology"? Not to attend to

63 Part of the pragmatist point against foundationalism is that these cannot be separated.

64 Church of the Lukumi Babalu Aye, Inc. v. Hialeah, 508 U.S. 520 (1993).

65 "Talking theology," which includes "talking about God" or trying "to determine exactly what counts as religion for the purposes of law," "is something that properly happens in churches and seminaries, or - at the very leastamong private citizens. It is certainly not something that a federal judge should be doing while on the bench. It is not something that the government should be doing at all" (IRF, 4). 
these facts concerning conceptions of the religion, its practices, their importance, and disputes about these things?

Imagine various versions of the Smith peyote case before a Supreme Court in a US-like legal system and running along a scale bounded by the following scenarios: ${ }^{66}$

Scenario A. At one end, notwithstanding legitimate governmental interest, the law's general applicability, and absence of animus, the court decides for Smith, granting an exemption in view of the fact that peyote use is central to his religion and religious freedom would otherwise be severely compromised. Any threat to public order is outweighed by his right to religious freedom, the wrong of compromising this individual's or community's capacity to practice their religion.

Scenario Z. At the other end, the court not only rules against Smith but declares that these practices are not religion. They throw in blinkered commentary about their irrationality, their dissimilarity to Christianity, and their departure from "civilized" ways. The judges show Smith blatant disrespect, failing to attend to or engage arguments on his behalf. It is a mere show of a trial.

We can imagine countless variations running the gamut from $\mathrm{A}$ to $\mathrm{Z}$, let alone those beyond $\mathrm{Z}-$ such as putting the verdict to referendum, deciding by coin toss, pursuing outright persecution. Who doubts there are vital differences here? That scenario $\mathrm{A}$ and $\mathrm{Z}$ differ radically in regard to justice, neutrality, and religious freedom? Would someone really want to say that scenario A exhibits the paradox of religious freedom, shows religious liberty to be domination, indicates inevitable bias toward belief over practice, or displays a privatizing impulse somehow essential to "the state" and "the secular"? So long as we can imagine scenario A, the new genealogy is misguided. Nothing proper to "the state" renders scenario A impossible. I see no sense in which scenario A fails to exhibit neutrality, let alone justice. ${ }^{67}$

Consider another scenario along the same scale:

Scenario L. The Court rules against Smith in view of the general applicability of the law, lack of animus, and (relatively minimal) threat to public order. It does so thanks precisely to its refusal to consider or entangle itself in judging the importance of the practice to this religion in the name of foundationalist Neutrality. They weigh only some undifferentiated, generic "religious value."

Compare scenario L to scenario A. In what way does scenario L exhibit a species of neutrality worth valuing? In what sense does it more deeply exhibit justice or honor religious freedom? I

66 Employment Division, Department of Human Resources of Oregon v. Smith, 494 U.S. 872 (I990).

67 My point is that "talking theology" is sometimes necessary for neutrality and justice, not that it is sufficient. Sometimes when courts "talk theology" things go badly-as some might suppose they did when Scalia said that the cross honored all war dead or when the European Court of Human Rights declared classroom crucifixes merely "cultural" and not "religious." But that is no objection to my point. Moreover, that "talking theology" might sometimes contribute to bad decisions does not show that evenhandedness and justice are better served by its proscription. To have reason to ban "talking theology" we would not only need to see that it somehow inevitably goes badly (which notion I have just given us reason to reject) but, further, that this badness would be always worse than the badness which certainly can come from proscribing it-which badness I have tried to demonstrate above. The argument that would ban "talking theology" because it sometimes goes badly would need to ban any dimension of the judicial process that could go wrong - which is every dimension! In any case, I have only tried to show how and why "talking theology" is sometimes necessary for evenhandedness and justice-not that it is sufficient. 
can think of none. If what it displays deserves to be called "neutrality," I hardly see what service it is to the cause of justice or religious freedom.

Now consider a set of variations on our first scenario:

Scenarios $A_{1}, A_{2}, A_{3}$, etc. Here, the facts of the case vary somewhat in each instance: the public interest is more (or less) compelling, the practice less (or more) central to the religion, or both. The verdict changes accordingly in view of the matrix between the relative importance of the public interest and the centrality of the practice-which the Court takes into account. Smith wins or loses accordingly.

Does this seem unjust? A failure of neutrality? Compare this to the set:

Scenarios $\mathrm{A}^{\mathrm{I}}, \mathrm{A}^{2}, \mathrm{~A}^{3}$, etc. Here, the facts of the case vary in identical ways as compared to the other set, but in all these cases the court foreswears considering the importance of the various practices or the teachings of the religion. Thus, their decision varies independently of anything to do with the practice's significance.

In what sense does this represent a gain for justice over the former set? For freedom? Do we imagine scenario A and iterations like it not to be just or principled? Is it no morally different from scenario $\mathrm{Z}$, let alone the horrendous, all too familiar alternatives not even on this scale?

To be very clear, I am not suggesting that most or even many religious freedom cases are like this - nor that governments cannot entangle themselves in theological matters or controversies in ways that would be violative of religious freedom. I mean, instead, to begin to enflesh a vision of evenhandedness unlike that shared by foundationalism and the new genealogy. On this view, attending to the particularities of a religious community or individuals, weighing the relative importance of some practice, discerning the differences made by local and broader contexts, in short, "talking theology," is not necessarily contrary to religious freedom or neutrality but often essential to it.

\section{Dialectical Religious Freedom: Judging Importance and "Talking Theology"}

Pursuing religious liberty involves judgments of importance, discerning how central or weighty some religious matter is. Such judgments seem inevitable. Implicitly or explicitly, hidden or public, ignorantly or informed, uncontested or subject to scrutiny, they will be made. If so, the best chance of their being made justly involves rendering the relevant commitments and reasoning public and contestable. Domination is more, not less, likely when such work proceeds without acknowledgement, scrutiny, or challenge. Pursued well, such activity does not violate religious freedom but helps constitute it. Fairness involves taking all the relevant facts into account. Among these are facts about the relative importance of various practices and commitments. Such weighing of goods and judgments of importance need not be arbitrary or unprincipled. They can be highly objective. In no religious tradition, community, or life is everything equally important in relation to everything else. Were everything equally important, nothing would be important at all.

Instead, religious communities, like other communities, have more or (often) less settled views on the relative significance of various practices and commitments-however rough, implicit, fluid, and revisable. Certainly, such matters are contested. Indeed, such contestations and the divisions they spur help define boundaries between communities, subgroups, and individuals. Nonetheless, we can find points of agreement, and corresponding judgments of importance, in virtue of which, for instance, we regard Sunnis and Shia as alike Muslims-or Muslims and Jews as, alike, 
monotheists. Such divisions instruct us about what is more or less important to whom and in what ways. And the same point holds, for instance, within Sunni Islam or Therevāda Buddhism-where such disagreements divide this group from that. Most simply, working carefully, we can accurately discern what is more or less important to some religious community-as various members and observers see it. The possibility of academic study of religion presupposes this point. We can say, for instance, that the Eucharist is more central to Catholicism and much of Christianity than foot washing, or that Passover is more important for most Jews than Chanukah. Yet such judgments are also profoundly context- and community-dependent. For certain Baptists, foot washing is more important than the Lord's Supper; for some Jews, Chanukah more important than Passover. All this can be taken into account as needed in some case.

When it comes to such discernment, we must attend to the practices and priorities of the communities and contexts in question-not just the broader communities of which they are part. It would be mistaken to assume that what is normative or important for some particular Muslim or Muslim community comports with what has been normative or important for most Muslims or Islam more generally. What we want is a sense of the relative importance in some case for this adherent or community. We cannot assume "normative" Islam (whatever that is) and then evaluate. Rather, we need to attend to what this adherent or community identifies as important, including which communities they regard most salient, whom they recognize and seek recognition from. This may be in continuity with "mainstream" strands of some tradition, but it may not. For one parish, the most salient community may be that parish; for another, it may be the "Church catholic." And the relative importance of some practice may vary accordingly. Thus, among the relevant facts are those related to the community's or individual's vision of their relation to still broader communities - and these may differ dramatically from what "mainstream" teaching about this relation suggests.

None of this suggests simply taking some adherent's "word for it," but of tacking dialectically between what she says and what we discern to be the case for some community. This fundamentally inductive approach accords local context and communities immense importance. ${ }^{68}$ What it rejects is the notion that attending to these matters is impossible or somehow compromises freedom. And it rejects approaches that are top-down, artificially formalized, or context-negligent. Such a priori, anti-dialectical approaches are exemplified in the expert testimony of Daniel Pals and Nathan Katz in a Florida trial concerning religious burial practices (IRF, I47-48). 69 They offer abstract, universalistic formulas as one-size-fits-all tests for judging religious authenticity and importance. As Winnifred Sullivan rightly notes, each predictably favors "mainstream," "dominant," institutionalized strands of tradition. $7^{\circ}$ Local practices are discounted as heterodox or lacking authority and so as less religious or important. My approach rejects such foundationalism but refuses to abandon efforts to judge relative importance. ${ }^{7 \text { I }}$

Distinct from but related to these importance issues, religious freedom conflicts also admit of different kinds, depending on what some practice means for some community. Say some state

68 Even when some community invokes "mainstream" or "orthodox" strands of their tradition, it is they who are doing so. These strands figure precisely because they are important for the community or adherent in question.

69 Warner v. Boca Raton, 64 F.Supp.2d I 272 (S.D. Fla. I999). And see IRF, appendix B, chapter 3, I29-37, and I44-52.

70 Katz problematically distinguishes between "high" traditions (institutional, "orthodox," and "by law") and "little" traditions (local, "personal," and "by custom"), declaring "little" traditions "ethnic" rather than religious. IRF, $72-78$, I $88-89$.

7I This demands no more of judges than what is expected in complex business (for example, derivatives trading) and scientific (for example, pharmaceutical patents) cases. 
interest impinges on some central practice, and suppose the state interest seems clearly weightier. Still, perhaps the practice is so important that it helps constitute a community as the very community it is. To subtract that practice is not merely to compromise the community but to violate it. And perhaps religious freedom requires security against violation. In this sense, some harms may compromise or even damage, but not every harm violates. Think, for instance, of the difference between a mugging in which someone is badly beaten and a sexual assault at knifepoint. Beyond bodily harm, we can consider the spiritual and psychic damage. Ceteris paribus, the sexual assault but not the mugging seems violative. This has to do with complex features such as the importance, intimacy, or centrality to self of what is attacked, the kind of vulnerability implicated, and so on, that resist formalized articulation. Likewise, whatever the bodily harm, if some mugging's motive were patently racist - the victim targeted for being black - it, too, could be violative, a "hate crime." And like sexual assault, its violative character will have to do with what precisely it attacks: this person as black. Most obviously, laws exhibiting animus against some religious group seem violative in this way-even if the apparent harm is minimal or the affected practice relatively unimportant. But what I am suggesting is that even apart from animus, compromising certain practices, even if they are not central, can amount to violation and thus be incompatible with religious liberty. As with the hate crime, context and history matter: even if circumcision were not so central to Judaism, its proscription in Germany amounts to something weightier than its proscription elsewhere.

When it comes to burdens and conflicts alike, multiple distinctions are salient for religious liberty. Alongside considerations of importance, we might distinguish among burdens, compromises, restrictions, and violations as naming different losses some religious community might suffer. And we can still further distinguish impacts in terms of scope, rationale, likely consequences, etc. ${ }^{72}$ Yet so much as to bring these distinctions in view requires "talking theology," attending to history and context, and gauging the importance of some practice for some community.

In all this, there is a distinction worth caring about between imperfect and perfect religious liberty. No religious liberty regime can guarantee that every believer is always without just complaint. But this does not mean that religious liberty is impossible or a tool of oppression. The inherent imperfection of religious liberty-inherent given the world we actually live in -is not the same as its absence or violation. Religious liberty comes in degrees. Some things seem altogether incompatible with it. But there are a wide range of arrangements and affairs in which religious freedom can count as present even as it is more or less perfectly realized. Perhaps we can further identify a narrower range wherein we regard a society as enjoying religious liberty. This will mean that there are basic, inviolable guarantees against religious coercion, persecution, discrimination, and the like. And beyond this, the legal system will guarantee that, in the inevitable conflicts and frustrating losses that invariably follow for some communities, the relevant decision-making processes themselves are nonarbitrary, manifesting respect, equity, contestability, and the like. This is what the scenario $\mathrm{A}-\mathrm{Z}$ thought experiments bring into view. 73 "Talking theology" and pursuing judgments of importance are certainly forms of interference and entanglement. But they are nonarbitrary and

72 And these will be mutually implicating - a retinue of relatively minor impacts affecting relatively peripheral practices could, together, amount to violation.

73 Insisting on such mechanisms is not proceduralism in any pernicious sense. These procedures matter just to the extent that they honor substantive values that have independent purchase and standing; the values render some procedure of value because and so far as the procedure helps secure or realize some value (for example, reciprocity, accountability, publicity). 
undertaken in order to render each her due under law. They do not compromise religious freedom; they make it possible.

\section{RESEMBLANCE AND DOMINATION}

In assessing whether something constitutes domination, the chief question concerns its resemblance to the master/slave relation. Such judgments require deciding which features, shared in which way, constitute resemblance. And this requires judgments of importance, which necessarily implicate our values and aims. Not everyone will always agree, for not everyone will share similar aims or a keen eye. Nonetheless, although non-foundationalist, judgments of resemblance can be reliable, principled, justified (both in being held and before others), and nonarbitrary. This matter of resemblance exemplifies dynamics that run through my entire approach to religious freedom.

Abstract formulations of domination (such as "subjection to arbitrary power") help make explicit the master/slave relation's distinctive injustice. Between such formulations and the paradigm there is dialectical give and take as we gauge some formulation's adequacy, consider actual cases of slavery, and recalibrate our grasp of the paradigm itself. One asks: Is this relation between boss and worker, governor and citizen, religion $\mathrm{X}$ and religion $\mathrm{Y}$, state and religion saliently like slavery? Is the worker, citizen, or religious minority at the mercy of the powerful? Do they regard the relationship good? Believe it tracks their interests? Can they look eye to eye or must they look down, defer, manipulate, flatter, self-censor, dissemble, avoid? When it comes to discerning whether some relation constitutes domination, abstract formulations, relational paradigms, and particular instance are all essential.

Now, consider the term arbitrary. Foundationalists will demand necessary and sufficient criteria for what constitutes arbitrariness, transcendentally validated grounding, and the like. That demand must be resisted. The notion of arbitrariness must itself be dialectically articulated, constantly revised and contested. We can adduce ad hoc principles. ${ }^{74}$ But these principles are neither perfectly determinate nor permanently fixed-nor our grasp of the paradigm, which itself will be shaped by particular cases of slavery and new arrangements we come to regard as dominating, and, again, particular instances of those relations, and vice-versa, all the way across the board.

Recall the earlier point concerning precedents. Suppose that in some deeply patriarchal society that does regard slavery as evil Mary is the first to name the male/female relation domination. Others follow. In so doing, she transforms her society's grasp of the relation (it is now viewed as dominating and slavish), but she also expands conceptions of domination and slavery. By so using them, she transforms her society's sense of what they name and authorizes others to use them still differently in the future. A dialectical view recognizes that each application of some principle or concept itself changes that principle or concept. Each new claim and recognition of resemblance affects our conception and grasp of slavery and the relations that now seems like it. When consensus builds around Mary's claim, patriarchal male/female relations become part of the paradigm of domination - and a precedent for recognizing still other relations as dominating, including

74 Elizabeth Anderson echoes my point: "We should be skeptical of attempts to operationalize the conditions for nondomination in formal terms. Powerful agents are constantly devising ways to skirt around formal constraints to dominate others," "Conceptions of Freedom and Equality," in The Oxford Handbook of Freedom, ed. David Schmitz and Carmen E. Pavel (Oxford: Oxford University Press, 20I6), 9I-94, at 92-93. I am bringing in view the futility of trying to articulate formalized necessary and sufficient condition; Anderson has in view the danger. Both considerations matter. 
those that may not have been so recognized without this new paradigm, the principles it inspires, or the revisions to conceptions of slavery and domination this new use of the term effects.

\section{DIALECTICS AND THE “VERY IDEA” OF RELIGION}

All we have seen regarding domination-in terms of the dialectical movement between paradigms, formulations, and new cases; the concept's contestability; its ever-changing, non-essentialist character-holds no less for the concept religion. They are both concepts, and concepts we can examine and deploy for particular aims, whether naming and resisting a certain injustice, as with domination, or securing freedom for a certain enduring, widespread range of social practices, as with religion. The meanings of domination and religion are in their use. This vision of concepts indicates a response to charges levied by the new genealogy and various scholars that the concept religion is necessarily biased, ideological, or otherwise problematic and makes good on a promissory note issued earlier.

A single concept or term can admit of a wide array of more or less related conceptions or definitions. Concepts do not have essences. Instead, they bear the meanings they have thanks to their role in social practices. Many concepts have multiple, relatively distinct roles. Religion is like this. It can vary widely as to what it is applied to: "The Red Sox are Boston's religion"; "Her religion is Judaism"; "Religion is bound to wither in the face of science"; "Without true religion, abolitionism would never have succeeded." These are some familiar usages of religion. None is more "correct" or "legitimate" than another. Each names something in our social world-and, incidentally, something different. Beyond varying in relation to its appropriate circumstances of application or that to which it is rightly applied, some concept (or conception) can vary dramatically in regard to what judgments, inferences, or acts its application authorizes. For a medieval Dominican, describing someone as having religion (religio) named a moral virtue acquired by habituation and conveyed praise and authorized admiration. An Irish Buddhist may use the term to refer to different phenomena (such as mastery of meditation postures) but may, likewise, authorize admiration in using it. When a "new atheist" like Sam Harris says someone has a religion, he thereby expresses and invites contempt. Some evangelicals who say they do not have a religion depart from Harris's usage as to circumstances of application (he would say they were paragons of religion) but share his negative stance toward those to whom they apply the term-adherents of "institutional" Christianity.

There are myriad conceptions of religion. That religio and then religion was used in such-and-such a way at some point in the past, even if that usage was, by contemporary lights, extremely different as to application or especially unsavory as to consequences, is eminently worth our sustained study. But it need have minimal bearing on some contemporary concept or usage. 75 Because there is no essence to the concept religion (or that to which it applies) and because there are multiple, distinct senses of the concept (and because strictly every use differs in some way from precedent usages) there is no reason to assume that some contemporary usage shares anything important in common with those aspects of past usages or conceptions that we regard suspect or problematic. Various conceptions of religion may have served colonialism, suggested that "belief" constituted religion, implied that Christianity was the "best" religion, and so on. But it is an open question as to what, if anything, some contemporary usage or conception has in common with

75 It need have minimal bearing - but it certainly can and often does have significant bearing. The issue here is necessity and what is possible for us to do with our concepts. 
them. It is certainly mistaken to think that problematic dimensions of some past conception inhere in all contemporary conceptions, least of all when someone rejects such dimensions in her conception or shows no evidence of them in her usage. To think otherwise is a species of the genetic fallacy. Indeed, consider that for nearly fifteen hundred years the term religio and its derivatives were primarily used to name a habit of good character, a virtue acquired by repeated performance of a certain formally defined set of activities. A cousin of the more general, cardinal virtue of justice, religio named a ready disposition to render due worship, service, and piety to the divine, to perform the communal and individual rites and bodily activities considered fitting service to God, gods, or the divine which, additionally, were understood to have innately political implications and value. Today, scarcely anyone uses "religion" to name a virtue, let alone imagines it an innately communal and political phenomenon. Having accidentally left this legacy almost entirely behind, there is no reason to think we could not deliberately excise dimensions of past-or extant-conceptions that we reject or regard as problematic, constructing instead a conception that best serves our aims.

Happily, we need not start from scratch. One common scholarly conception of religion familiar to most English speakers includes the so-called world religions and a host of other historical and contemporary social practices that religion scholars have found useful to call religion. Many of these scholars vehemently and cogently reject precisely those features of earlier conceptions that the new genealogy regards problematic. $7^{7}$ Some offer formulations for how they think we should conceive and use the concept. There is no reason to think that because of the concept or term religion's history, such usage exhibits bias, essentializes religion, or is otherwise problematic. Whether some particular conception is problematic depends on that conception and usage, not a history of the concept generally, let alone some other conception.

We can bring our concepts into view (using still other concepts), refine and debate them, ask whether they suit our aims, and revise accordingly. 77 This is the case with domination. So, too, with religion. Because our purposes are many when it comes to religion and to scholarship or law in relation to religion, our conceptions can be many as well. Even when it comes to religious freedom, there is no prima facie reason to think that we need just one conception of religion. Yet even if we did, it would remain that, like any other, this conception would itself always already be undergoing change.

As with domination, one promising strategy for conceptualizing religion is similarly pragmatic, holist, ad hoc, and dialectical. Rather than seeking necessary and sufficient criteria, it begins with diverse paradigm cases-Hinduism, Judaism, Native American religions, Yoruba, and so on-and builds from there. One compares new cases to paradigm cases. This involves judgments of resemblance and thus importance, deciding which features and dimensions are saliently similar. There is no permanent, universal formula. One tacks between particular cases, more abstract paradigms, and best-to-date efforts, making explicit what the cases seem to show. This is how we operate with countless concepts across all sorts of domains of life. Confronting some new case, we put it alongside paradigm cases and best-to-date formulations. And we ask again what aims the conception should serve. Acknowledging that there has been a tendency to prioritize one feature or dimension over others, one takes corrective action, attending to what had been occluded-practices, say. If there has been bias toward Christianity, one prioritizes other paradigms, like Buddhism. By so

76 See, for example, Bush, Visions of Religion, and Kevin Schilbrack, Philosophy and the Study of Religions: A Manifesto (Malden: Wiley-Blackwell, 20I4).

77 The suggestion here is not de novo concept creation but the point that we can go to work on some particular conception and refine and clarify it according to our interests and aims-and we can use the concept so understood. 
correcting, newly recognized cases of religion become precedents and paradigms for future cases, transforming the conception still further. Throughout, one can err on the side of inclusion.

If there are multiple conceptions of freedom, there are at least as many-and almost certainly a great many more-conceptions of religion. There is no such thing as the very idea of religion or religious freedom, no essence such that it can be put on trial and found guilty or not. Provided it avoids pathologies and prima facie bias, what matters is whether a given definition of religion or religious freedom is useful. ${ }^{78}$

Religion is a non-natural sortal. It marks out some domain of human practice in a more or less intelligible and coherent way. A decent definition will clearly include many things and exclude many others. But as a non-natural sortal, boundary cases are inevitable. Vagueness will attach to such cases. Yet here, religion is like nearly any important concept associated with law-life, speech, commerce, press, race, protected class, gender, and the like. For any of these, there will be countless clear cases and various boundary cases. This does not suggest a problem with these concepts. Vagueness need not become an occasion for arbitrariness, domination. Decisions on such boundary cases can themselves proceed nonarbitrarily. And while zones of vagueness will become sights of contestation, that contestation need not devolve into a battle for mastery or an occasion for unchecked sovereignty or discretion. It can instead be a sight for reciprocity, respect, and exchange of reasons so that, even in loss, one can recognize some rationality at play-as Scenarios $A_{1}, A_{2}, A_{3}$, etc. display. This is the promise of a functioning, just judicial system. If someone wants to insist otherwise, they will need to expand their critique to nearly every domain in which rights or law are implicated, for religion is no more or less vague or contested than countless other concepts. 79

Any act of defining is an act of power. The important question is whether that act is an act of arbitrary power, domination. When one weds the promise of some recent conceptions of religion to the sorts of dialectical processes of reciprocity, accountability, contestability, and publicity I have sketched above, we have good reason to think efforts to define religion in order to honor and enact religious freedom can avoid domination. ${ }^{\circ}{ }^{\circ}$ We can further mitigate that risk by building in a commitment to permissiveness rather than parsimony, erring on the side of counting as religion what might not be. We must recall too that the risk posed by hazarding definitions of religion is not the only one we face. For, in the absence of efforts to secure religious liberty, some will certainly be dominated by others on religious grounds or for religious reasons - whether we call them that or not.

\section{RELIGIOUS FREEDOM AFTER THE POLITICS OF RELIGIOUS FREEDOM}

People and their governments do things to other people, sometimes violent and even horrendous things, for reasons. Among the reasons for which people act are religious reasons, reasons having to do with beliefs, institutions, and practices related to religious matters. People and communities not only act for religious reasons - in the sense of acting on the basis of their own convictions and

78 Schilbrack, Philosophy and the Study of Religions, I I 5-I6.

79 It would be more than a little ironic if the new genealogy wanted to insist that religion, as a concept or phenomenon, was somehow sui generis. BRF, I2 I-22, seems to suggest just that. "Religion," Hurd says, "is too unstable a category" to figure in law (BRF, 6, I3, I2I; and see 67).

80 See, for example, Bush, Visions of Religion; Schilbrack, Philosophy and the Study of Religions; Tyler Roberts, Encountering Religion: Responsibility and Criticism (New York: Columbia University Press, 20I3); Lewis, Why Philosophy Matters. 
practices and to achieve goals related thereto-they also act upon and in relation to others because of the others' perceived religious identity. They act in certain ways because they regard others as religious. An atheist despises a Muslim because she is Muslim. A Christian attacks a Jew because she is Jewish. Hindu and Muslim communities terrorize one another because they regard their opponents to be idolaters. A secular government persecutes a religious group because a majority or secular elite regards that group's religion noxious. Such occurrences are all too familiar. This is not the only reason religious believers persecute, attack, or kill others or the only reason those who are religious suffer such things. But it is one of them. It is undeniable that religious identity and commitments figure in action upon and by religious communities and individuals.

Though obvious, these points remind us of what is actually at stake in the new genealogy's assault on religious freedom. What religious freedom, at its best, is meant to do is to recognize the reality that people act for religious reasons -in both senses-and to try to secure religious and nonreligious folks against domination insofar as it implicates these matters. Some of the most destructive violation of religious freedom has been at the hands of modern "secular" states that seek the annihilation of religious groups. Religious freedom concerns itself not only with the threat of majorities dominating minorities and the religiously powerful dominating vulnerable co-religionists, but with the state itself dominating individuals or communities. There can be no doubt that religious freedom has sometimes been constructed in ways that enact and conceal rather than prevent and expose domination. I join the new genealogy of religious freedom in condemning that as reprehensible.

But that is not the only thing religious freedom has served to do. It is certainly not what religious freedom has to be, not least because religious freedom does not have to be anything. In its vehement critique of foundationalist religious freedom, the new genealogy seems to collapse most of the distinctions that matter. It does so in a way that is itself unstable, if not self-consuming. It rejects domination. But domination seems to be the only thing it can find at play in religious freedom or state action. One is left wondering how the new genealogy's critique is not itself just another expression of the will to power.

If the new genealogy of religious freedom is serious about rejecting domination, it has to allow for the workings of things other and better than the will to mastery in human interchange and contemporary political life. It has to distinguish between power differentials generally and that pernicious species we call domination. Ironically, in its instability and power-reductionist leanings, the new genealogy actually buttresses its foundationalist opponents, including those who refuse to recognize the ways religious freedom or religious freedom activism can sometimes serve as a tool of domination. In a way akin to removing legal protections for racial minorities, the new genealogy would leave the religiously vulnerable subject to domination. If the only alternative were the ongoing domination-in-disguise of foundationalism, this might seem worth the risk. I have tried to show that these are not the only alternatives.

There is more to religious freedom than the politics of it. And there is more to politics than the will to mastery. Religious freedom-the only religious freedom I care about-seeks to secure the socially and politically vulnerable against mastery by the powerful, whether the state, fellow citizens, or co-religionists. This is not identical to an attempt to turn the tables, to replace mastery with mastery. It is an effort at something better-if not political friendship, at least mutual recognition. To paraphrase Abraham Lincoln: As I would not be a slave, so I would not be a master. This expresses my idea of religious freedom. Whatever differs from this, to the extent of the difference, is not religious freedom. 